\title{
Climate controls on tree growth in the Western Mediterranean
}

\author{
Ramzi Touchan,' Kevin J Anchukaitis,' David M Meko,' \\ Dalila Kerchouche, ${ }^{2}$ Said Slimani, ${ }^{3}$ Rachid IImen, ${ }^{4}$ Fouad Hasnaoui, ${ }^{5}$ \\ Frederic Guibal, ${ }^{6}$ Jesus Julio Camarero, ${ }^{7}$ Raúl Sánchez-Salguero, ${ }^{8}$ \\ Alma Piermattei, ${ }^{9,10}$ Abdessadek Sesbou, ${ }^{1}$ Benjamin I Cook, ${ }^{12}$ \\ Mohamed Sabir," and Hayat Touchane ${ }^{13}$
}

\begin{abstract}
The first large-scale network of tree-ring chronologies from the western Mediterranean ( $\mathrm{WM} ; 32^{\circ} \mathrm{N}-43^{\circ} \mathrm{N}, 10^{\circ} \mathrm{W}-17^{\circ} \mathrm{E}$ ) is described and analyzed to identify the seasonal climatic signal in indices of annual ring width. Correlation and rotated empirical orthogonal function analyses are applied to 85 treering series and corresponding gridded climate data to assess the climate signal embedded in the network. Chronologies range in length from 80 to II 29 years. Monthly correlations and partial correlations show overall positive associations for Pinus halepensis (PIHA) and Cedrus atlantica (CDAT) with winter (December-February) and spring (March-May) precipitation across this network. In both seasons, the precipitation correlation with PIHA is stronger, while CDAT chronologies tend to be longer. A combination of positive correlations between growth and winter-summer precipitation and negative partial correlations with growing season temperatures suggests that chronologies in at least part of the network reflect soil moisture and the integrated effects of precipitation and evapotranspiration signal. The range of climate response observed across this network reflects a combination of both species and geographic influences. Western Moroccan chronologies have the strongest association with the North Atlantic Oscillation.
\end{abstract}

\section{Keywords}

chronology development, cubic smoothing spline, expressed population signal, general circulation models, North Africa, palmer drought index

Received 22 October 2016; revised manuscript accepted 12 January 2017

\section{Introduction}

The Mediterranean Basin has suffered through several severe droughts in recent decades (e.g. Adjez, 2000; Chbouki, 1992; Cook et al., 2016; Isendahl and Schmidt, 2006; Nicholson and Wigley, 1984; Swearingen, 1992; Touchan et al., 2008a, 2011). Such events often have drastic social and economic impacts, particularly in North Africa (NA) where freshwater and surface water supplies are extremely limited (Isendahl and Schmidt, 2006) and climate variability is an important influence on food security and political stability (Meyers, 1981; Schilling et al., 2012; Swearingen, 1992). The 1980-1985 drought in Morocco resulted in a $1.5 \%$ drop in the country's Gross National Product and a $2 \%$ drop in industrial production (Berrada, 1982), while river flow decreased 50-90\% (Chbouki, 1992) and many natural lakes became completely dry (Belkheiri et al., 1987). In 1945, a severe drought in NA devastated agriculture there (Swearingen, 1988, 1992), killed half of the sheep flock in Morocco (Hazell, 2000), and resulted in widespread regional famine (Kassoul and Maougal, 2006). The 1999-2002 drought across NA was by some metrics the worst short-term event since at least the middle of the 15th century (Masih et al., 2014; Touchan et al., 2008a, 2011). And while drought is a reoccurring feature of the last century in the western Mediterranean (WM), of even greater concern for water resources is that climate models consistently project future long-term drying in the Mediterranean because of increased greenhouse gas forcing over the course of the next century (Collins et al., 2013; Cook et al., 2014; Giorgi and Lionello,
2008; Seager et al., 2014). This is linked to both a future decline in winter rainfall as well as an increase in temperatures and

\footnotetext{
'University of Arizona, USA

${ }^{2}$ Institute of Veterinary and Agronomy Sciences, The University of Batna, Algeria

${ }^{3}$ Faculty of Biological Sciences and Agronomy, Mouloud Mammeri University of Tizi-Ouzou, Algeria

${ }^{4}$ Department of Hydraulic, Environment and Climate (HEC), Hassania School of Public Works, Morocco

Institute of Sylvo-pastoral of Tabarak, Tunisia

6Mediterranean Institute for Biodiversity and Ecology of Marine and

Continental, France

${ }^{7}$ Pyrenean Institute of Ecology (IPE) - CSIC, Spain

${ }^{8}$ Department of Physical, Chemical and Natural Systems, Universidad

Pablo de Olavide, Spain

${ }^{9}$ Swiss Federal Institute for Forest, Snow and Landscape Research WSL, Switzerland

10Marche Polytechnic University, Italy

"National School of Forestry Engineering, Morocco

${ }^{12}$ National Aeronautics and Space Administration (NASA) Goddard Institute for Space Studies, USA

${ }^{13}$ Faculty of Agriculture, University of Aleppo, Syria
}

Corresponding author:

Ramzi Touchan, University of Arizona, I2I5 E. Lowell Street, Building no. 45, Tucson, AZ 85721, USA.

Email: rtouchan@Itrr.arizona.edu 
evaporative demand (Cook et al., 2014; Scheff and Frierson, 2015; Zappa et al., 2015).

Improved knowledge and understanding of the full range of past hydroclimatic variability over WM is critical for improved understanding of factors driving that variability, assessing the representation of low-frequency climate variability in general circulation models (GCMs), and placing current hydroclimate conditions in a long-term context (Cook et al., 2016; Touchan et al., 2008a, 2011). A few continuous high-quality instrumental data series in NA start in the early 1900 s, but the majority of instrumental observations cover only the latter half of the 20th century (Hoerling et al., 2012). Proxy records, such as tree rings, allow for the development of quantitative and validated paleoclimate drought reconstructions to assist in understanding climate variability on time scales beyond that of the instrumental data (Fritts, 1976). While a systematic analysis of the seasonal climate signal in tree-ring records from the eastern Mediterranean showed coherent patterns of response over large regions (e.g. Touchan et al., 2014), the climate signal for a range of tree species over the broader Mediterranean region has until now not been characterized.

Here, we describe and analyze a network of tree-ring chronologies in the WM $\left(32^{\circ} \mathrm{N}-43^{\circ} \mathrm{N}, 10^{\circ} \mathrm{W}-17^{\circ} \mathrm{E}\right)$ collected and developed over the period from 2002 to 2015 . We analyze the climate signal embedded in this network as a necessary step prior to its application to the study of long-term climate variability, the association between regional climate and atmosphere-ocean circulation, and the ability of GCMs to reproduce important drought-related features of regional climate. The objective of the analysis is to guide and refine paleoclimate reconstruction protocols, including the selection of appropriate target reconstruction and climate models fields, all with the larger goal of understanding Mediterranean climate variability at interannual to centennial scales, providing out-of-sample assessment of GCMs, and evaluating the myriad interacting influences on WM droughts. Our analysis also provides insight into how climate controls forest growth and productivity in the region (e.g. Babst et al., 2013; Vicente-Serrano et al., 2013).

\section{Materials and methods}

\section{Tree-ring data and chronology development}

This study describes the outcome of the first large-scale systematic dendroclimatic sampling focused on developing a network of drought-sensitive chronologies from WM including Morocco, Algeria, and Tunisia, with additional new sites from southeastern Spain, Corsica, and southern Italy. Fieldwork was conducted over the period 2002-2015 and resulted in development of 85 chronologies from 86 sites (Table 1 and Figure 1). Samples were collected from species previously shown to form annual rings (Cherubini et al., 2003; Choury et al., 2016; Touchan and Hughes, 1999; Touchan et al., 2005, 2008a, 2008b, 2011). Increment cores and full cross sections from stumps were taken from cedar, oak, and pine species (Table 1). Samples were surfaced and cross-dated following standard dendrochronological techniques (Stokes and Smiley, 1968). The width of each annual ring on the cores and cross-sections was measured to the nearest $0.01 \mathrm{~mm}$ using a VELMEX measurement system (Velmex Inc., 2016).

Here, each series of tree-ring width measurements was fit with a ' $67 \% \mathrm{~N}$ ' cubic smoothing spline (frequency response 0.50 at a wavelength $2 / 3$ the sample length) to remove non-climatic trends due to age, size, and the effects of stand dynamics (Cook and Kairiukstis, 1990). The detrended series were then pre-whitened with low-order autoregressive models to remove persistence not related to climatic variations. The individual residual indices were combined into single averaged chronologies for each combination of site and species using a bi-weight robust estimate of the mean (Cook and Holmes, 1999; Cook and Krusic, 2005).

We used the expressed population signal (EPS), calculated from data on sample size and between-tree correlation, to assess the adequacy of replication of the chronology (Wigley et al., 1984). The EPS estimates the ability of a finite-sample to approximate the true, unknown, population tree-ring signal at the site. Following recommended guidelines (Cook and Kairiukstis, 1990; Wigley et al., 1984), we judged a chronology as adequately sampled for use in climatic reconstruction (e.g. precipitation and drought index) if the chronology EPS reaches 0.85 before the start of the instrumental climate record.

\section{Observational climate data}

Previous analyses have shown that tree growth in the WM is controlled by soil moisture and precipitation (Aloui, 1982; Aloui and Serre-Bachet, 1987; Camarero et al., 2013; Chbouki, 1992; Chbouki et al., 1995; Esper et al., 2007; Linares et al., 2011; Messaoudene and Tessier, 1997; Safar et al., 1992; Serre-Bachet, 1969; Slimani et al., 2014; Tessier et al., 1994; Till and Guiot, 1990; Touchan et al., 2008a, 2008b, 2011). We compared our chronology network against the gridded, self-calibrating, Penman-Monteith Palmer Drought Severity Index (PDSI; Van der Schrier et al., 2013) covering 1901-2009 and $1.0^{\circ}$ gridded monthly precipitation data from the Global Precipitation Climatology Centre (GPCC; version 6) dataset covering 1901-2010 (Becker et al., 2013; Schneider et al., 2011, 2013). For temperature data, we used high-resolution $0.5^{\circ}$ gridded temperature data from the Climatic Research Unit (CRU) TS3.23 dataset (Harris et al., 2014) covering the period from 1901 to 2014. We also used the North Atlantic Oscillation (NAO) index from Jones et al. (1997) to assess the relationship between our chronologies and largescale North Atlantic climate.

We conducted a site-by-site correlation analysis of each residual ring-width chronology against the nearest gridded climate data using the seasonal correlation (SEASCORR) procedure developed by Meko et al. (2011) with exact simulation (Percival and Constantine, 2006) for significance testing. We used the individual monthly as well as seasonal values by calculating the sum (precipitation) or average (PDSI and temperature) over winter (December-February (DJF)), spring (March-May (MAM)), or the water year (October-June and October-September). We considered a 14-month window starting in the August prior to the growth year and ending in the following September (e.g. Fritts, 1976; Meko et al., 2011; Touchan et al., 2008b).

In order to assess common signals among our chronologies, we performed a rotated (Varimax; Kaiser, 1958) empirical orthogonal function (EOF) analysis on our network. EOF analysis isolates patterns of covariance in a collection of individual time series into a few leading uncorrelated and orthogonal modes (Jolliffe, 2002; Navarra and Simoncini, 2010). These mathematical constraints may, however, not accurately reflect the underlying climatic or ecological structure of the network (Monahan et al., 2009). Relaxation of the orthogonality constraints by rotation of the eigenvectors can allow for identification of 'simple' or localized modes of variability (Richman, 1986). We performed the EOF analysis over the common period spanned by all chronologies (1934-2003), with each chronology first normalized to a mean of zero and standard deviation of 1 . The spatial patterns of the leading rotated EOF (REOF) modes were subsequently analyzed for their association with climate and ocean-atmosphere modes.

\section{Results and discussion}

\section{Tree-ring chronologies}

Data for individual tree-ring chronologies are summarized in Tables 1 and 2. The lengths of the 85 chronologies range from 80 years (Tekrouna, Tunisia) to 1129 years (Col de Zad, 
Table I. Site information for Western Mediterranean.

\begin{tabular}{|c|c|c|c|c|c|c|c|c|c|}
\hline Country & Site Name & Site Code & Species $^{\mathrm{a}}$ & Elevation (m) & $\begin{array}{l}\text { Latitude } \\
\text { (Degree) }\end{array}$ & $\begin{array}{l}\text { Longitude }^{b} \\
\text { (Degree) }\end{array}$ & $\begin{array}{l}\text { Time Span } \\
\text { (Year) }\end{array}$ & $\begin{array}{l}\text { Total No. } \\
\text { of Years }\end{array}$ & $\begin{array}{l}\text { No. of Trees/ } \\
\text { Cores }\end{array}$ \\
\hline \multirow[t]{26}{*}{ Morocco } & Adeldal & ADD & PIPI & 900 & 35.90 & -5.47 & $1843-2004$ & 162 & $20 / 39$ \\
\hline & Tazaot & TAZ & ABMA & 1636 & 35.27 & -5.11 & $1812-2012$ & 201 & $20 / 40$ \\
\hline & Tisouka & TIS & ABMA & 1775 & 35.18 & -5.20 & $1763-2004$ & 242 & $20 / 37$ \\
\hline & Madisouka & MAK & PINI & 1350 & 35.17 & -5.13 & $1847-2005$ & 159 & $15 / 28$ \\
\hline & Afechtal & AFE & CDAT & 1800 & 35.03 & -4.98 & $1623-2004$ & 382 & $34 / 74$ \\
\hline & Tizarine & TIZ & CDAT & 1743 & 35.02 & -4.90 & $|720-20| \mid$ & 292 & $20 / 40$ \\
\hline & Bab Larz & BAL & CDAT & 1655 & 34.96 & -4.66 & $|625-20| \mid$ & 387 & $21 / 42$ \\
\hline & Jbel Dahdouh & $\mathrm{JBD}$ & CDAT & 1792 & 34.91 & -4.60 & $|857-20| \mid$ & 155 & $20 / 4 I$ \\
\hline & Dahdoh Issaguen & DAH & CDAT & 1832 & 34.91 & -4.60 & $|80|-20||$ & 201 & $19 / 37$ \\
\hline & Machraa Hamadi & MAH & PIHA & 820 & 34.69 & -2.64 & $|923-20| \mid$ & 89 & $20 / 39$ \\
\hline & Tazzeka & TAK & CDAT & 1875 & 34.08 & -4.18 & $|594-20| \mid$ & 418 & $45 / 83$ \\
\hline & Lala Mimouna & LAM & PIHA & 1084 & 34.02 & -2.88 & $190 \mid-2013$ & 113 & $22 / 44$ \\
\hline & Ich Ramouz & ICR & CDAT & 1825 & 33.78 & -5.03 & 1349-2004 & 656 & $20 / 39$ \\
\hline & Tizi n Treten & TRN & CDAT & 1890 & 33.47 & -5.02 & $1490-2003$ & 514 & $23 / 52$ \\
\hline & Chmi n'Qtaan & $\mathrm{ICl}$ & CDAT & 1889 & 33.38 & -5.12 & $|560-20| \mid$ & 452 & $22 / 45$ \\
\hline & Ain Khala & AIK & CDAT & 1986 & 33.24 & -5.23 & $|680-20| \mid$ & 332 & $22 / 46$ \\
\hline & Oum Rmel & OUR & CDAT & 1813 & 33.19 & -5.33 & $|674-20| \mid$ & 338 & $20 / 39$ \\
\hline & Senoual & SEN & CDAT & 2060 & 33.00 & -5.24 & $|305-20| \mid$ & 707 & $50 / 108$ \\
\hline & Col Du Zad & ZAD & CDAT & 2203 & 32.98 & -5.07 & $883-2011$ & 1129 & $104 / 182$ \\
\hline & Tadkaline & TAD & CDAT & 1824 & 32.80 & -5.23 & $|722-20| \mid$ & 290 & $20 / 44$ \\
\hline & Taourirt & TAO & CDAT & 1875 & 32.75 & -4.05 & $1479-2004$ & 526 & $21 / 43$ \\
\hline & Jbel Jafaar & JAF & CDAT & 2118 & 32.53 & -4.90 & 889-20II & 1123 & $66 / 117$ \\
\hline & Tounfite & TOU & CDAT & 2150 & 32.47 & -5.33 & $|3| 8-20||$ & 694 & $40 / 84$ \\
\hline & Bouizourane & $\mathrm{BOI}$ & CDAT & 2175 & 32.45 & -5.32 & $1268-2004$ & 737 & $20 / 42$ \\
\hline & Afrasko & AFR & CDAT & 2543 & 32.38 & -5.00 & $|256-20| \mid$ & 756 & $38 / 74$ \\
\hline & Tadlounte & TAA & CDAT & 1923 & 32.37 & -5.57 & 1696-2004 & 309 & $32 / 60$ \\
\hline \multirow[t]{32}{*}{ Algeria } & Athmane & ATH & QUAF & 1080 & 36.67 & 4.57 & $|82|-2005$ & 185 & $15 / 22$ \\
\hline & Thamguiguelt & THT & CDAT & 1550 & 36.47 & 4.02 & $1747-2005$ & 259 & $20 / 36$ \\
\hline & Refuge Amirouche & REA & CDAT & 1557 & 36.47 & 4.01 & $|647-20| \mid$ & 365 & $20 / 40$ \\
\hline & Igni inguel & IGI & CDAT & 1443 & 36.47 & 4.00 & $|62|-2005$ & 385 & $20 / 40$ \\
\hline & Djamaa Tighrifine & DJT & CDAT & 1460 & 36.45 & 4.10 & $|534-20| \mid$ & 478 & $50 / 95$ \\
\hline & Tigounatine & TIG & CDAT & 1697 & 36.45 & 4.10 & $|552-20| \mid$ & 460 & $40 / 79$ \\
\hline & Lfidh Mohand Ouali & LMO & CDAT & 1519 & 36.45 & 4.11 & $|697-20| \mid$ & 315 & $40 / 79$ \\
\hline & Reserve Pinus nigra & RPN & PINI & 1558 & 36.45 & 4.10 & $1569-2005$ & 437 & $20 / 40$ \\
\hline & Thala Gaidawane & THG & CDAT & 1380 & 36.43 & 4.20 & $|64|-2005$ & 365 & $20 / 37$ \\
\hline & Kerrach & KER & CDAT & 1398 & 36.42 & 2.88 & $|849-20| \mid$ & 163 & $21 / 43$ \\
\hline & Pèpinière Parasol & PEP & CDAT & 1452 & 35.85 & 1.98 & $1533-2012$ & 480 & $40 / 78$ \\
\hline & Kef Sahchine & KES & CDAT & 1560 & 35.85 & 2.00 & $|7| 7-20||$ & 295 & $41 / 80$ \\
\hline & Guetiane & GUE & CDAT & $175 \mid$ & 35.69 & 5.52 & $|440-20| \mid$ & 572 & $42 / 82$ \\
\hline & Bordjem & BOR & CDAT & 1876 & 35.59 & 6.04 & || $47-20||$ & 865 & $50 / 95$ \\
\hline & Boumerzoug & $\mathrm{BOU}$ & CDAT & 1517 & 35.59 & 6.08 & $1679-2009$ & 331 & $20 / 27$ \\
\hline & Ain Kerrouche & AIK & CDAT & 1674 & 35.57 & 6.04 & $1306-2009$ & 703 & $38 / 73$ \\
\hline & Tizi Ala & TIA & CDAT & 1522 & 35.38 & 6.96 & $|384-20| \mid$ & 628 & $26 / 52$ \\
\hline & Ain El Halfa & AEH & CDAT & 1756 & 35.33 & 6.90 & $1070-2012$ & 943 & $49 / 91$ \\
\hline & Oued Tider & OUT & CDAT & 2073 & 35.31 & 6.63 & $1002-2014$ & 1013 & $69 / 150$ \\
\hline & Ichmoul & $\mathrm{ICH}$ & CDAT & 1877 & 35.30 & 6.49 & $|40|-2012$ & 612 & $45 / 91$ \\
\hline & Theniet Zamroune & $\mathrm{THZ}$ & CDAT & 1970 & 35.30 & 6.63 & $912-2012$ & 1101 & $45 / 94$ \\
\hline & Aksra & AKS & PIHA & 1413 & 35.28 & 6.66 & $|85|-20||$ & 161 & $2 I / 4 I$ \\
\hline & Djeniene & DJE & PIHA & 1303 & 35.21 & 6.47 & $|834-20| \mid$ & 178 & $40 / 80$ \\
\hline & Taghda & TAG & CDAT & 1704 & 35.17 & 6.15 & $1830-2014$ & 185 & $25 / 53$ \\
\hline & Bout-Chaout & $\mathrm{BOC}$ & PIHA & 1273 & 35.13 & 6.62 & $1695-201 \mid$ & 317 & $45 / 79$ \\
\hline & Besbassa & BES & PIHA & 1223 & 34.93 & 3.43 & $|887-20| \mid$ & 125 & $22 / 45$ \\
\hline & Bahrara & $\mathrm{BAH}$ & PIHA & 1134 & 34.81 & 3.25 & $|875-201|$ & 137 & $21 / 42$ \\
\hline & Tobji & TOB & PIHA & $133 \mid$ & 34.62 & 3.13 & $|85|-20||$ & 161 & $40 / 79$ \\
\hline & Thniet N'ser & THN & PIHA & 1386 & 34.61 & 3.09 & $|830-20| \mid$ & 182 & $42 / 81$ \\
\hline & Faijat El Bagra & FEB & PIHA & 1334 & 34.56 & 2.78 & $|794-201|$ & 218 & $31 / 57$ \\
\hline & Al Khadra & ALK & PIHA & 1357 & 34.55 & 2.80 & $|853-20| \mid$ & 159 & $21 / 43$ \\
\hline & Zebbache & ZEB & PIHA & 1415 & 34.53 & 3.01 & $|835-20| \mid$ & 177 & $21 / 40$ \\
\hline \multirow[t]{4}{*}{ Tunisia } & Remal Bizzerte & REM & PIHA & 32 & 37.25 & 9.92 & $1916-2012$ & 97 & $51 / 94$ \\
\hline & Oued Zen & ouz & QUCA & 556 & 36.78 & 8.78 & $|688-20| \mid$ & 324 & $23 / 33$ \\
\hline & Ain Dhalia & AID & QUCA & 711 & 36.48 & 8.30 & $1684-2003$ & 320 & $15 / 30$ \\
\hline & Tekrouna & TEK & PIHA & 537 & 36.32 & 8.44 & $1934-2013$ & 80 & $19 / 36$ \\
\hline
\end{tabular}


Table I. (Continued)

\begin{tabular}{|c|c|c|c|c|c|c|c|c|c|}
\hline Country & Site Name & Site Code & Species $^{\mathrm{a}}$ & Elevation $(m)$ & $\begin{array}{l}\text { Latitude } \\
\text { (Degree) }\end{array}$ & $\begin{array}{l}\text { Longitude }^{b} \\
\text { (Degree) }\end{array}$ & $\begin{array}{l}\text { Time Span } \\
\text { (Year) }\end{array}$ & $\begin{array}{l}\text { Total No. } \\
\text { of Years }\end{array}$ & $\begin{array}{l}\text { No. of Trees/ } \\
\text { Cores }\end{array}$ \\
\hline & Dahllia & DHA & PIHA & 982 & 36.25 & 8.44 & $|890-20| \mid$ & 122 & $31 / 61$ \\
\hline & Djebel El Koucha & DEK & PIHA & 793 & 36.19 & 8.35 & $1860-2012$ & 153 & $20 / 39$ \\
\hline & Sadine & SAD & PIHA & 376 & 36.11 & 8.50 & $|75|-20||$ & 261 & $44 / 85$ \\
\hline & Jebnoun & JEB & PIHA & 801 & 35.85 & 9.31 & $|874-20| \mid$ & 138 & $36 / 71$ \\
\hline & Faden-Ahmed & FAA & PIHA & 947 & 35.84 & 9.35 & $|898-20| \mid$ & 114 & $20 / 38$ \\
\hline & Ain Oum Jeddour & $\mathrm{AOJ}$ & PIHA & 1024 & 35.64 & 8.94 & $|905-20| \mid$ & 107 & $20 / 39$ \\
\hline & Kef Laagab & KEL & PIHA & 1105 & 35.63 & 8.96 & $1922-2012$ & 91 & $20 / 39$ \\
\hline & Oum Djedour & OUD & PIHA & 1050 & 35.58 & 8.93 & 1865-2004 & 140 & $20 / 28$ \\
\hline \multirow[t]{5}{*}{ Corsica } & Assco Forest & ASF & PINI & 1475 & 42.40 & 8.92 & $1423-20 \mid 3$ & 591 & $20 / 42$ \\
\hline & Melo & MEL & PINI & $165 \mid$ & 42.32 & 9.06 & $\mid 747-2013$ & 267 & $20 / 60$ \\
\hline & Capu Valendru & CAV & PINI & 1490 & 42.29 & 8.97 & $|48|-20 \mid 3$ & 533 & $19 / 58$ \\
\hline & Col de Saltu & CDS & PINI & 1433 & 42.28 & 8.83 & $1386-2013$ & 628 & $20 / 40$ \\
\hline & Puzz Atelli & PUZ & PINI & $|48|$ & 42.14 & 9.12 & $1440-2013$ & 574 & $20 / 61$ \\
\hline \multirow[t]{5}{*}{ Italy } & Tagliola & TAG & PILA & 1566 & 39.42 & 16.58 & $|830-20| 4$ & 185 & $25 / 53$ \\
\hline & Macchia Dell Arpa & ARP & PILA & 1625 & 39.13 & 16.67 & $|898-20| 4$ & 117 & $20 / 37$ \\
\hline & Piani di Luncadi & PDI & PILA & 1736 & 38.16 & 15.93 & $|753-20| 4$ & 262 & $23 / 46$ \\
\hline & Piani di Luncadi & PDIA & ABAL & 1729 & 38.16 & 15.94 & $|76|-20 \mid 4$ & 254 & $20 / 41$ \\
\hline & Naca & NAC & PILA & 1568 & 38.15 & 15.96 & $17|5-20| 4$ & 300 & $22 / 45$ \\
\hline \multirow[t]{5}{*}{ Spain } & $\begin{array}{l}\text { Puerto de las } \\
\text { Palomas }\end{array}$ & PDP & PINI & 1237 & 37.94 & -2.94 & $1819-2014$ & 196 & $21 / 42$ \\
\hline & Collado de la Zarca & $\mathrm{CDZ}$ & PINI & 1671 & 37.92 & -2.83 & $1670-2014$ & 345 & $20 / 40$ \\
\hline & $\begin{array}{l}\text { Caňada de las } \\
\text { Fuentes }\end{array}$ & CDF & PINI & 1598 & 37.85 & -2.96 & $1800-20 \mid 5$ & 216 & $22 / 42$ \\
\hline & $\begin{array}{l}\text { Ermita Jardín } \\
\text { Botánico }\end{array}$ & EJB & PIHA & 1444 & 37.70 & -2.21 & $1923-20 \mid 4$ & 92 & $21 / 4 \mid$ \\
\hline & El Pinar Bayarque & EPB & PIHA & 1133 & 37.32 & -2.47 & $1910-2014$ & 105 & $22 / 44$ \\
\hline
\end{tabular}

aSpecies Key: PIPI (Pinus pinea), ABMA (Abies marocana), PINI (Pinus nigra), CDAT (Cedrus atlántica), PIHA (Pinus halepensis), QUAF (Quercus afares), QUCA (Quercus canariensis), PILA (Pinus laricio), ABAL (Abies alba)

${ }^{b}$ Negative indicates west longitude

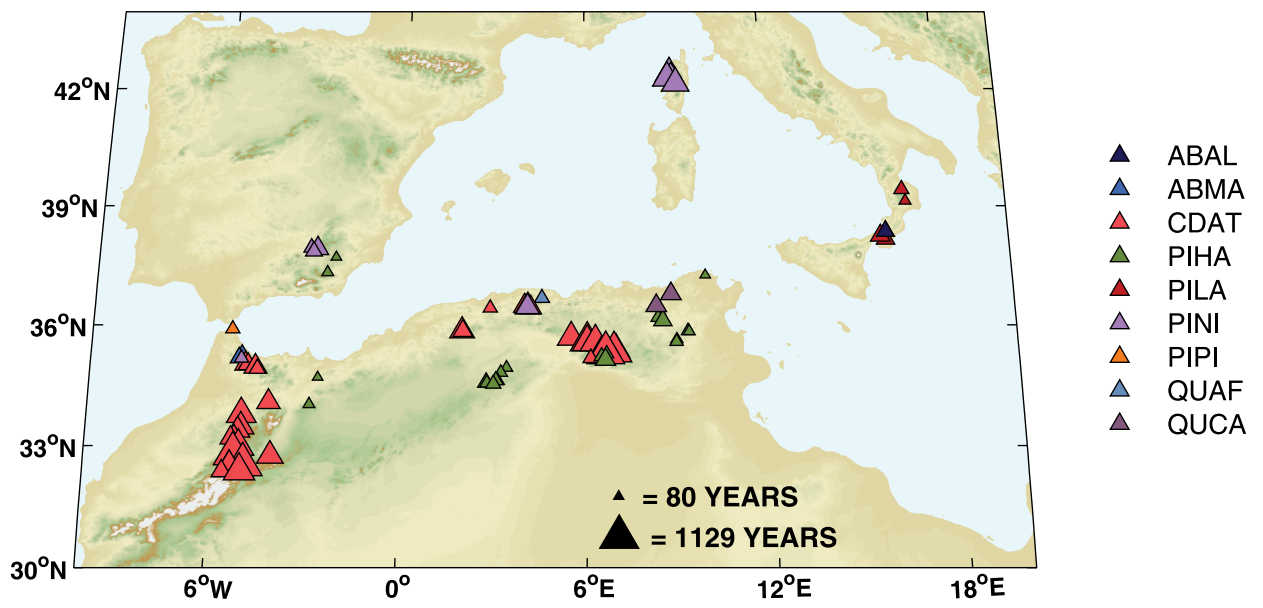

Figure I. Location of tree-ring sites. Colors correspond with the species shown in the legend (see Table I for species codes) and size of the symbols reflects the length of the chronology.

Morocco) (Table 1, Figure 2). Some difficulty was found in cross-dating some of the Pinus halepensis (PIHA) samples in Algeria and Tunisia because of the incidence of locally absent rings (approximately $3.4 \%$ in Tunisia $4.4 \%$ in Algeria) and intra-annual boundaries (false rings) at the lower elevation in Tunisia (REM and SAD). Several papers addressed the same difficulties in dating PIHA with false rings in the WM (e.g. Camarero et al., 2010; Cherubini et al., 2003; Choury et al., 2016; De Luis et al., 2011). Statistical analyses of each chronology are summarized in Table 2 . The mean correlation among individual radii at each site (the interseries correlation) ranges from 0.26 to 0.79 . The highest interseries correlation is for the BES site in Algeria and the lowest is for the chronology developed from the TAG site in Southern Italy. The mean sample segment length (MSSL) of all 85 chronologies ranges from 56 to 420 years. Thirty-two percent of these chronologies have an MSSL greater than 200 years in length and several have MSSL exceeding 400 years. Figure 1 shows the distribution of chronologies across the study domain. The network (Figure 1 ) is dominated by Cedrus atlantica (CDAT; $n=41)$ and PIHA ( $n=$ 24) in Morocco, Algeria, and Tunisia. Pinus nigra (PINI; $n=$ 10) was collected in Corsica, Algeria, Southeastern Spain, and Morocco. Other species in our network are represented by fewer than four sites.

A major objective of our collection is to obtain the longest possible tree-ring records from living and dead trees in order to investigate climate variability over several centuries or the last millennium. Throughout most of the NA and WM, we have been 


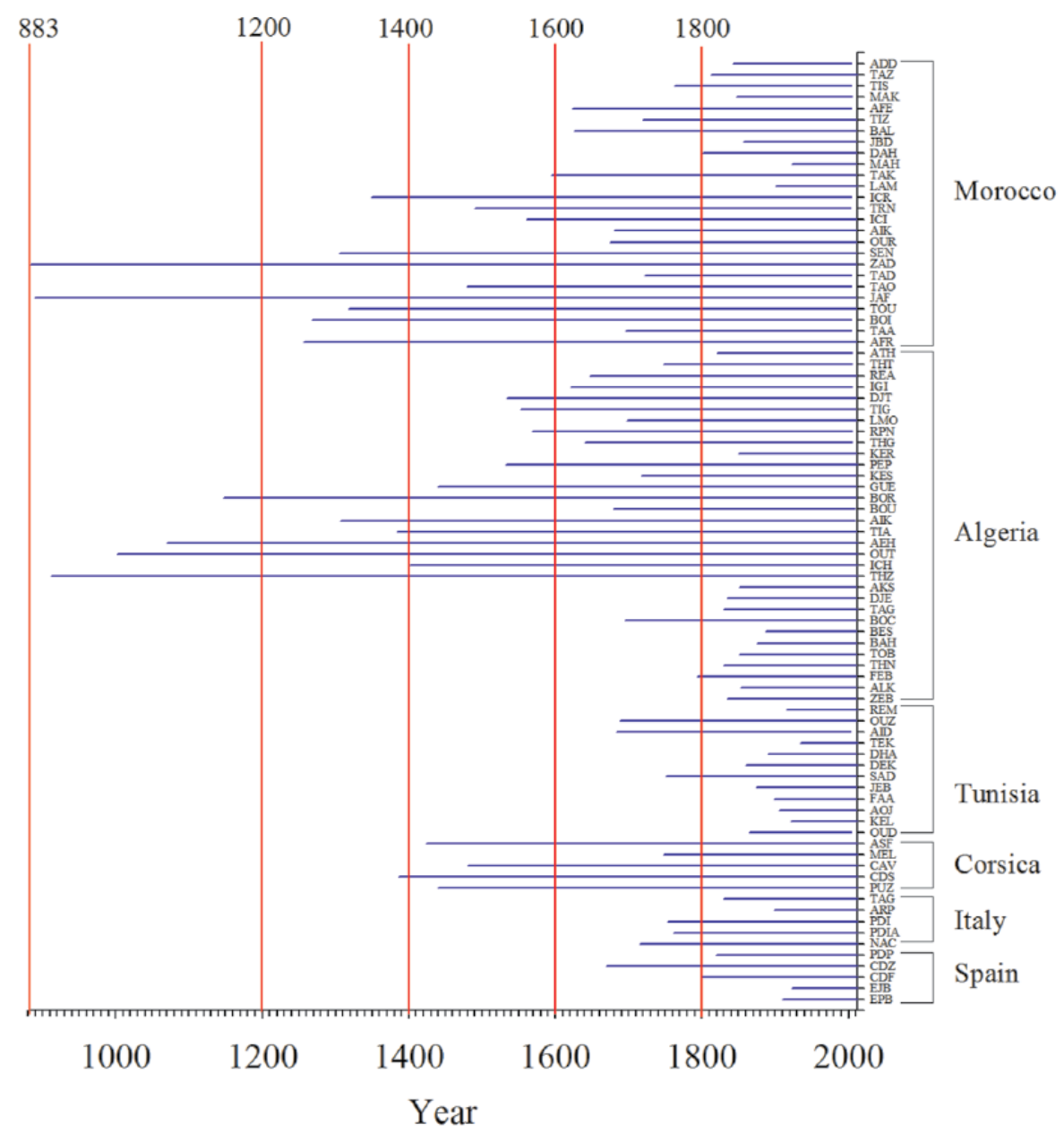

Figure 2. Time coverage of the chronologies. Each horizontal line marks the time span of the chronology whose letter code appears by the right-hand scale.

Table 2. Summary statistics for the 85 chronologies for the ARSTAN program (Cook and Holmes, 1999; Cook and Krusic, 2005).

\begin{tabular}{|c|c|c|c|c|c|c|c|c|c|}
\hline \multirow[t]{2}{*}{ Country } & \multirow[t]{2}{*}{ Site Code } & \multicolumn{4}{|c|}{ Total Chronology } & \multicolumn{4}{|c|}{ Common Interval } \\
\hline & & $\mathrm{MSSL}^{\mathrm{a}}$ & $S t d^{b}$ & $\mathrm{SK}^{\mathrm{c}}$ & $K U^{d}$ & $\begin{array}{l}\text { Ist Year } \\
\text { EPS }>0.85\end{array}$ & Time Span & $M^{\prime} C A R^{f}$ & Evg PCl (\%) \\
\hline \multirow[t]{24}{*}{ Morocco } & ADD & 99 & 0.13 & -0.15 & 1.38 & 1914 & $|944-200|$ & 0.36 & 38 \\
\hline & TAZ & 157 & 0.15 & 0.21 & 0.48 & $|84|$ & $|880-20| \mid$ & 0.45 & 47 \\
\hline & TIS & 166 & 0.13 & 0.04 & -0.12 & 1839 & $1870-2003$ & 0.32 & 35 \\
\hline & MAK & 93 & 0.12 & -0.01 & 0.01 & 1942 & $|933-200|$ & 0.32 & 36 \\
\hline & AFE & 236 & 0.14 & -0.12 & 0.01 & 1657 & $1772-2002$ & 0.44 & 46 \\
\hline & TIZ & 162 & 0.17 & -0.49 & 1.27 & 1799 & $|852-20| \mid$ & 0.38 & 46 \\
\hline & BAL & 172 & 0.22 & -0.46 & -0.44 & 1729 & $|90|-20||$ & 0.48 & 50 \\
\hline & JBD & 118 & 0.19 & -0.33 & 6.40 & 1872 & $190 \mid-2010$ & 0.52 & 54 \\
\hline & DAH & 105 & 0.22 & 0.50 & 3.94 & $189 \mid$ & $|922-20| \mid$ & 0.51 & 54 \\
\hline & MAH & 74 & 0.41 & 0.67 & 1.29 & $192 \mid$ & $|954-20| \mid$ & 0.59 & 62 \\
\hline & TAK & 218 & 0.21 & -0.41 & 1.52 & 1645 & $1872-2004$ & 0.47 & 48 \\
\hline & LAM & 93 & 0.37 & 0.60 & 2.53 & 1906 & $|93|-20||$ & 0.65 & 67 \\
\hline & ICR & 393 & 0.19 & -0.86 & 2.15 & 1416 & |573-1972 & 0.47 & 51 \\
\hline & TRN & 117 & 0.22 & 0.33 & 6.61 & 1631 & $1842-2000$ & 0.49 & 51 \\
\hline & $\mathrm{ICl}$ & 238 & 0.20 & -0.35 & 2.46 & 1750 & $1816-2010$ & 0.43 & 45 \\
\hline & AlK & 189 & 0.19 & -0.59 & 3.91 & I77| & $|875-20| \mid$ & 0.51 & 53 \\
\hline & OUR & 196 & 0.20 & -0.53 & 3.04 & 1797 & $1842-2007$ & 0.43 & 44 \\
\hline & SEN & 324 & 0.20 & -0.63 & 1.39 & 1329 & $1631-1920$ & 0.49 & 50 \\
\hline & ZAD & 420 & 0.25 & -0.39 & 4.29 & 915 & $1496-1840$ & 0.54 & 56 \\
\hline & TAD & 112 & 0.26 & -0.54 & 0.75 & 1837 & |944-20|| & 0.63 & 65 \\
\hline & TAO & 245 & 0.26 & -1.16 & 2.06 & 1682 & |793-1999 & 0.48 & 51 \\
\hline & JAF & 311 & 0.35 & -0.31 & 0.16 & 1123 & $1757-1965$ & 0.60 & 62 \\
\hline & TOU & 265 & 0.34 & -0.20 & 0.06 & 1369 & $1806-2004$ & 0.64 & 65 \\
\hline & $\mathrm{BOI}$ & 303 & 0.35 & -0.19 & 0.08 & 1452 & $1682-1998$ & 0.65 & 67 \\
\hline
\end{tabular}


Table 2. (Continued)

\begin{tabular}{|c|c|c|c|c|c|c|c|c|c|}
\hline \multirow[t]{2}{*}{ Country } & \multirow[t]{2}{*}{ Site Code } & \multicolumn{4}{|c|}{ Total Chronology } & \multicolumn{4}{|c|}{ Common Interval } \\
\hline & & $\mathrm{MSSL}^{\mathrm{a}}$ & Std $d^{b}$ & $\mathrm{SK}^{\mathrm{c}}$ & $K U^{d}$ & $\begin{array}{l}\text { Ist Year } \\
\text { EPS }>0.85\end{array}$ & Time Span & $M^{\prime} C A R^{f}$ & $\mathrm{Ev}^{\mathrm{g}} \mathrm{PCl}(\%)$ \\
\hline & TAA & 203 & 0.26 & -0.83 & 2.30 & 1726 & $|80|-1980$ & 0.61 & 63 \\
\hline & AFR & 389 & 0.39 & $-0.6 \mathrm{I}$ & 0.03 & $|32|$ & $1588-1980$ & 0.69 & 70 \\
\hline \multirow[t]{32}{*}{ Algeria } & ATH & 136 & 0.22 & 0.50 & 1.88 & 1854 & $1863-2002$ & 0.47 & 51 \\
\hline & THT & 133 & 0.18 & -0.98 & 3.03 & 1839 & $1917-2005$ & 0.45 & 48 \\
\hline & REA & 179 & 0.15 & -0.18 & 1.80 & 1806 & $1902-2010$ & 0.43 & 45 \\
\hline & IGI & 216 & 0.16 & -0.08 & 0.71 & 1722 & $1796-2004$ & 0.42 & 45 \\
\hline & DJT & 174 & 0.18 & -0.63 & 2.01 & 1635 & $181 \mid-2005$ & 0.43 & 46 \\
\hline & TIG & 220 & 0.19 & -0.98 & 2.45 & 1714 & $1884-2005$ & 0.34 & 37 \\
\hline & LMO & 123 & 0.16 & -0.70 & 4.18 & 1795 & $1922-2004$ & 0.41 & 43 \\
\hline & RPN & 155 & 0.16 & -1.05 & 5.43 & $187 \mid$ & $|849-200|$ & 0.37 & 42 \\
\hline & THG & 148 & 0.17 & -0.25 & 0.80 & 1885 & $1902-2004$ & 0.41 & 44 \\
\hline & KER & 104 & 0.21 & -0.07 & 0.49 & 1904 & $1920-2009$ & 0.48 & 50 \\
\hline & PEP & 134 & 0.26 & -0.03 & 0.55 & 1735 & $1922-2006$ & 0.64 & 65 \\
\hline & KES & 134 & 0.20 & 0.18 & 0.87 & 1799 & $1917-2006$ & 0.55 & 56 \\
\hline & GUE & 247 & 0.16 & -0.25 & 0.62 & 1596 & $1769-2009$ & 0.42 & 43 \\
\hline & BOR & 274 & 0.20 & -0.27 & 1.74 & 1416 & $1795-2006$ & 0.59 & 60 \\
\hline & BOU & 187 & 0.29 & -0.17 & 0.38 & 1753 & $|89|-199 \mid$ & 0.59 & 61 \\
\hline & AIK & 162 & 0.30 & -0.01 & 0.45 & 1638 & $1903-1995$ & 0.60 & 61 \\
\hline & TIA & 252 & 0.24 & -0.45 & 1.07 & 1610 & $1690-196 \mid$ & 0.58 & 60 \\
\hline & AEH & 271 & 0.51 & 0.51 & 4.28 & 1212 & $1777-2005$ & 0.70 & 71 \\
\hline & OUT & 370 & 0.23 & -0.41 & 1.65 & 1170 & 1736-1999 & 0.58 & 59 \\
\hline & $\mathrm{ICH}$ & 333 & 0.26 & -0.30 & 0.82 & 1546 & $1729-1999$ & 0.58 & 59 \\
\hline & $\mathrm{THZ}$ & 379 & 0.28 & -0.30 & 0.53 & 1338 & $1651-1993$ & 0.60 & 62 \\
\hline & AKS & 113 & 0.42 & 0.06 & 0.31 & 1856 & $1906-2010$ & 0.75 & 76 \\
\hline & DJE & 124 & 0.42 & 0.36 & 0.58 & 1850 & $1911-2006$ & 0.74 & 75 \\
\hline & TAG & 137 & 0.32 & 0.06 & 0.67 & 1819 & $|905-20| \mid$ & 0.71 & 72 \\
\hline & $\mathrm{BOC}$ & 160 & 0.49 & 0.73 & 2.16 & 1756 & $190 \mid-2006$ & 0.76 & 76 \\
\hline & BES & 75 & 0.39 & 1.40 & 5.30 & 1893 & $|964-20| \mid$ & 0.79 & 79 \\
\hline & BAH & 102 & 0.43 & 0.98 & 2.11 & 1883 & $|9| 5-201 \mid$ & 0.78 & 79 \\
\hline & ТОВ & 142 & 0.39 & 0.53 & 2.20 & 1854 & |889-2006 & 0.68 & 69 \\
\hline & THN & 121 & 0.34 & 0.78 & 3.24 & 1844 & $1897-2006$ & 0.68 & 69 \\
\hline & FEB & 122 & 0.42 & 0.92 & 2.57 & 1796 & $|909-20| \mid$ & 0.76 & 77 \\
\hline & ALK & 115 & 0.36 & 0.72 & 2.74 & 1866 & $|924-20| \mid$ & 0.74 & 75 \\
\hline & ZEB & 144 & 0.38 & 0.75 & 2.79 & 1842 & $|88|-20||$ & 0.75 & 76 \\
\hline \multirow[t]{12}{*}{ Tunisia } & REM & 83 & 0.24 & 0.41 & 1.30 & 1925 & $|933-20| \mid$ & 0.51 & 53 \\
\hline & ouz & 122 & 0.25 & 0.54 & 0.56 & 1896 & $1930-2003$ & 0.38 & $4 I$ \\
\hline & AID & 166 & 0.24 & 0.69 & 0.95 & 1882 & 1899-2003 & 0.39 & 42 \\
\hline & TEK & 56 & 0.28 & 0.98 & 3.91 & 1943 & $|934-20| \mid$ & 0.52 & 55 \\
\hline & DHA & 78 & 0.26 & 0.60 & 2.38 & 1899 & $|950-200|$ & 0.59 & 61 \\
\hline & DEK & 102 & 0.38 & 0.48 & 0.89 & 1885 & $1922-2010$ & 0.64 & 65 \\
\hline & SAD & 116 & 0.45 & 0.28 & -0.02 & 1756 & $1926-1990$ & 0.72 & 73 \\
\hline & JEB & 74 & 0.37 & 1.45 & 4.35 & 1911 & $1920-2000$ & 0.51 & 57 \\
\hline & FAA & 81 & 0.44 & 0.83 & 1.84 & 1907 & $1946-2010$ & 0.73 & 74 \\
\hline & $\mathrm{AOJ}$ & 79 & 0.39 & 0.96 & 1.73 & 1916 & |944-20|| & 0.76 & 77 \\
\hline & KEL & 58 & 0.30 & 0.63 & 0.55 & 1937 & $|968-20| \mid$ & 0.70 & 72 \\
\hline & OUD & 111 & 0.34 & 0.46 & 0.35 & 1871 & $1917-2004$ & 0.67 & 68 \\
\hline \multirow[t]{5}{*}{ Corsica } & ASF & 342 & 0.17 & 0.04 & 1.97 & 1552 & $1650-2013$ & 0.42 & 46 \\
\hline & MEL & 156 & 0.16 & 0.45 & 1.17 & $|79|$ & $|89|-2013$ & 0.49 & 51 \\
\hline & CAV & 223 & 0.22 & 0.28 & 1.07 & 1804 & $1867-2013$ & 0.43 & 45 \\
\hline & CDS & 257 & 0.28 & 0.40 & 0.80 & 1657 & $1827-2000$ & 0.51 & 53 \\
\hline & PUZ & 311 & 0.22 & 0.17 & 0.28 & 1558 & $1816-2013$ & 0.57 & 58 \\
\hline \multirow[t]{5}{*}{ Italy } & TAG & 125 & 0.13 & 0.15 & 0.15 & 1903 & $1938-20 \mid 4$ & 0.26 & 29 \\
\hline & ARP & 80 & 0.15 & 0.27 & 0.13 & $193 \mid$ & $1959-2013$ & 0.40 & 39 \\
\hline & PDI & 144 & 0.23 & -0.02 & 2.03 & 1863 & $|903-20| 4$ & 0.44 & 46 \\
\hline & PDIA & 150 & 0.22 & 2.03 & 17.83 & 1862 & $1906-2013$ & 0.39 & 41 \\
\hline & NAC & 238 & 0.20 & 0.39 & 0.27 & 1752 & $|823-20| 4$ & 0.40 & 42 \\
\hline \multirow[t]{5}{*}{ Spain } & PDB & 153 & 0.20 & 0.20 & 0.58 & 1850 & $|878-20| 4$ & 0.34 & 36 \\
\hline & $\mathrm{CDZ}$ & 242 & 0.26 & 0.33 & 1.85 & $|70|$ & $1812-2009$ & 0.49 & 51 \\
\hline & CDF & 155 & 0.25 & -0.28 & 1.34 & 1921 & $1843-2015$ & 0.46 & 51 \\
\hline & $\mathrm{EJB}$ & 75 & 0.24 & 0.19 & -0.32 & 1928 & $1954-2014$ & 0.53 & 55 \\
\hline & EPB & 80 & 0.39 & 1.23 & 3.21 & 1919 & $1948-2014$ & 0.77 & 77 \\
\hline
\end{tabular}

aMSSL is Mean Sample Segment Length

bStd is Standard Deviation

cSK is skewness

dKU is Kurtosis

eEPS is Expressed Population Signal (Wigely et al., 1984)

FMCAR is Mean Correlation Among Radii

$\mathrm{gEV}$ is Explained Variance 
able to collect samples that were several hundred years in age Multicentury mean segment lengths ensure that the series span sufficient time to be adequate for the investigation of multidecadal and centennial climate variability when combined with conservative detrending and standardization (Cook et al., 1995).

\section{Climate signal}

Single month correlations with local precipitation and partial correlations with local temperatures are shown in Figure 3. In Morocco, tree-ring chronologies are positively correlated with winter through summer (January-July) precipitation. At the seasonal scale (Figure 4), chronologies in Morocco's High Atlas Mountains reveal both winter (DJF) and spring (MAM) total precipitation and strong and significant correlations with OctoberJune and October-September (water year) total precipitation (Figure 5). These observations are in good agreement with the October-June precipitation reconstruction for Tunisia by Touchan et al. (2008b) and October-September precipitation reconstruction for Morocco (AD 1100-1977) by Till and Guiot (1990). In western Morocco, chronologies also reflect a negative response to spring-summer temperatures, likely through evapotranspiration influences on soil moisture, as well as a positive response to winter temperatures. Tree-ring chronologies at lower elevations in Morocco show no coherent or significant association with precipitation at the monthly, seasonal, or water year time scales. In southeastern Spain, PINI and PIHA chronologies have overall weaker correlations, in many cases insignificant, with monthly and seasonal precipitation (Figures 3 and 4), but over longer time scales, they do have significant positive correlations with integrated water year precipitation (Sánchez-Salguero et al., 2012), albeit weaker than observed for chronologies in Morocco (Figure 5).

In Algeria, tree-ring chronologies from CDAT, PIHA, and PINI have a mixed growth response to winter, spring, and summer precipitation (Figures 3 and 4). The strongest monthly correlations are with spring (March-May) precipitation, with a secondary winter (DJF) signal, particularly in the western mountain regions of Algeria (Slimani et al., 2014). Touchan et al. (2016) identified January-June total precipitation as the most appropriate seasonal predictand for reconstruction using 10 PIHA chronologies from Algeria. These monthly and seasonal signals integrate to give tree-ring chronologies in Algeria a strong and significant water year precipitation signal (Figure 5), with only two exceptions at more coastal sites. Subsets of tree-ring chronologies from northern Algeria have a negative response to December precipitation and a positive correlation with December and January temperatures (Kherchouche et al., 2012). Sites designated IGI, REA, THT, DJT, RPN, TIG, LMO, and THG are located in the National Park of Djurdjura, KER is located in the National Park of Chréa, and KES and PEP are situated in the National Park of Thniet el Had (see Table 1). The first two national parks are near the Mediterranean Sea (about $50 \mathrm{~km}$ ), within one of the most humid zones in Algeria (Meddi and Toumi, 2013; Meddour, 2010; Touazi and Laborde, 2004), with a mean annual precipitation around 1500 $2000 \mathrm{~mm}$ for the massif of Djurdjura (Touazi and Laborde, 2004) and about $1400 \mathrm{~mm}$ for Chréa (Halimi, 1980). Mean annual precipitation in Thniet el Had Park is around $708 \mathrm{~mm}$, and December is the wettest month (Chai and Kerrour, 2015). The negative response to December precipitation could be because of several possible mechanisms. Low winter soil temperatures associated with wet conditions can reduce absorption of water directly by decreasing the permeability of roots to water and indirectly by increasing the viscosity of water (Gates, 1980; Kozlowski, 1987; Suvanto, 2014). These responses to low soil temperature are often similar to those induced by soil water deficit (Benzioni and Dunstone, 1988; Vernieri et al., 1991), and affect productivity at times when soil water normally is not limiting (Pavel and Fereres,
1998). Snow may also play an important role in tree growth, as low air temperature extends bud dormancy and persistent snow cover may delay the onset of growth. This phenomenon is usually more pronounced at high elevations (Holobâcă et al., 2015). A third mechanism may be via heavy rain, which can cause soil waterlogging which prevents water absorption from the roots, and can lead to root suffocation (Kozlowski, 1987; Kozlowski and Pallardy, 1997; Parent et al., 2008; Stokes, 2000).

Algerian sites with significant correlations to winter, spring, and summer precipitation also have negative partial correlations with spring and summer (April-August) temperature. Chronologies in Tunisia follow a similar climate response pattern as observed in Algeria, with a broad winter-through-early summer monthly and seasonal response to precipitation (Figures 3 and 4), and therefore a strong and significant water year integrated climate signal (Figure 5). Exceptions to this pattern in Tunisia are for two Quercus canariensis chronologies and one short coastal PIHA chronology. In Tunisia, as in Algeria and western Morocco, negative partial correlations with spring and summer temperature indicate that the influence of evapotranspiration on soil moisture is an additional control on tree growth. Touchan et al. (2012) used the process-based VS (Vaganov-Shashkin) model to investigate the controls on growth in a PIHA tree-ring chronology. The model simulation revealed that soil moisture was the first order limit on tree growth (approximately $70 \%$ of the growth season) with a secondary control by temperature via limitation on growth the earliest part of the growing season (prior to April).

In Southern Italy and Corsica, climate controls on tree growth are weaker than observed in NA, with precipitation correlations largely confined to late spring and early summer (Figure 3; Battipaglia et al., 2009; Carrer et al., 2010; Hertze et al., 2014; Todaro et al., 2007). Winter precipitation correlations at these sites are weak (in some cases negative) and mostly insignificant (Figure 4). Not surprisingly, this leads to weak and insignificant correlations with integrated water year precipitation (Figure 5).

Our network is dominated by two species, CDAT $(n=41)$ and PIHA $(n=24)$. Both species show overall positive associations with winter (DJF) and spring (MAM) precipitation across our network (Figure 6). In both seasons, the precipitation correlation with PIHA is stronger overall; however, CDAT chronologies tend to be longer (Figures 1 and 2). The range of climate response observed across our network appears to reflect a combination of both species influences and geography. For instance, although PIHA chronologies have the strongest overall precipitation climate signal across our network, in southeastern Spain, the climate signal in this species is substantially weaker (Figure 4). While PIHA has a winter (DJF) signal in Tunisia, it has a spring (MAM) precipitation signal in southeastern Spain (Figure 4).

Patterns of climate correlation of chronologies in the WM are less coherent spatially than those reported for the eastern Mediterranean by Touchan et al. (2014). In that region, the primary pattern was positive growth response to May-June precipitation. In contrast to the results reported here for the $\mathrm{WM}$, in the eastern Mediterranean, there is an absence of a strong positive growth response to winter precipitation signal at high elevation sites.

A combination of positive correlations between growth and winter-summer precipitation and negative partial correlations with growing season temperatures suggests that chronologies in at least part of the network reflect soil moisture and the integrated effects of precipitation and evapotranspiration. Correlations with May-August PDSI (Touchan et al., 2008a, 2008b, 2011; Van der Schrier et al., 2013) are positive and highly significant particularly in Algeria and Tunisia, as well as western Morocco (Figure 7), corresponding to those sites and regions where temperature was negatively correlated to growth (Figure 3 ).

At sites with weak precipitation signals, however, in eastern Morocco, Southeastern Spain, Corsica, and Southern Italy, there 
NO $1 \perp \forall 7 \exists y y$ O NO $I \perp \forall \perp l d I$ כ $\exists$ dyd

tr.

站
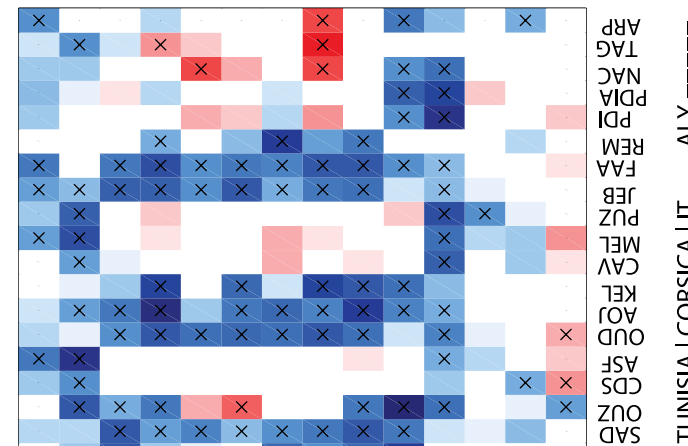

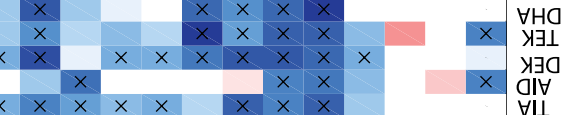

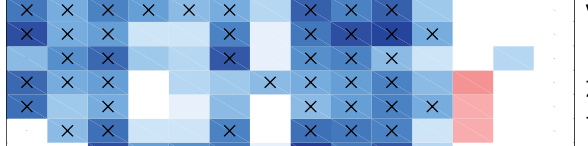

\section{\begin{tabular}{|l|l|}
\hline$x$ & $x$ \\
$x$ & $x$ \\
$x$ & $x$ \\
$x$ & \\
$x$ \\
$x$ \\
$x$ \\
$x$ \\
$x$ \\
$x$ \\
$x$ \\
$x$ \\
$x$ \\
$x$ \\
$x$ \\
\hline
\end{tabular}}
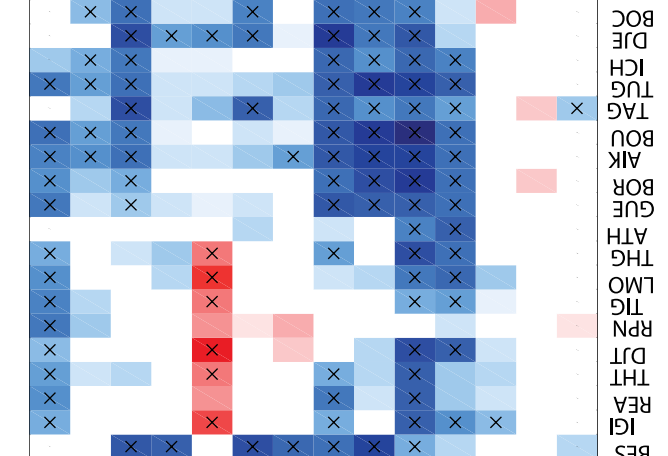

음
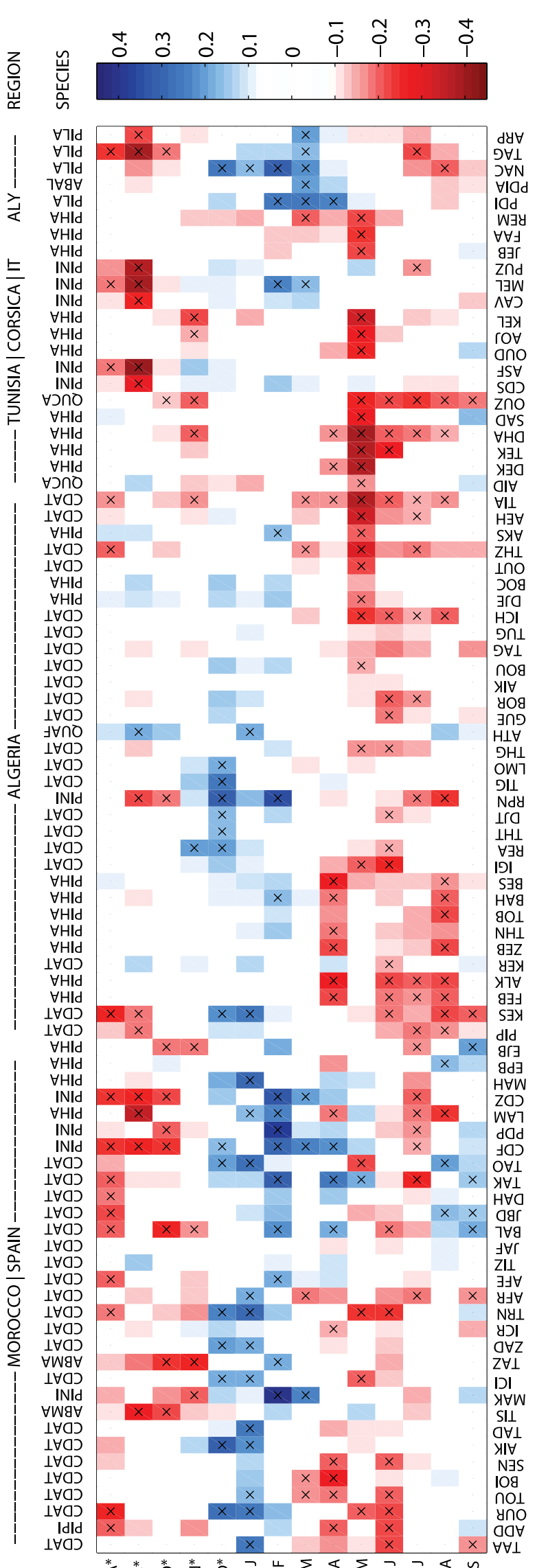

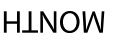

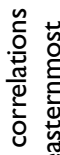

蛋先

要

ले

을

तं

๑ั

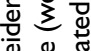

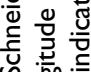

ํㅡ응

공ํㅇ

लं

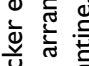

@

있

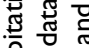

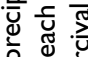

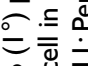

$>0$ 品

पु

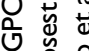

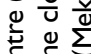

U.

崩

焉

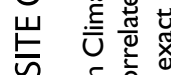

ऽ

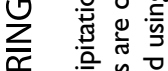

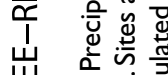

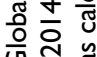

告

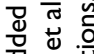

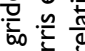

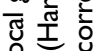

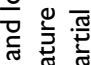

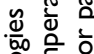

응 ह

을

는 옹

架

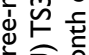

웡

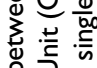

돈

읋

잉

응

줗를

六

m

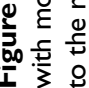



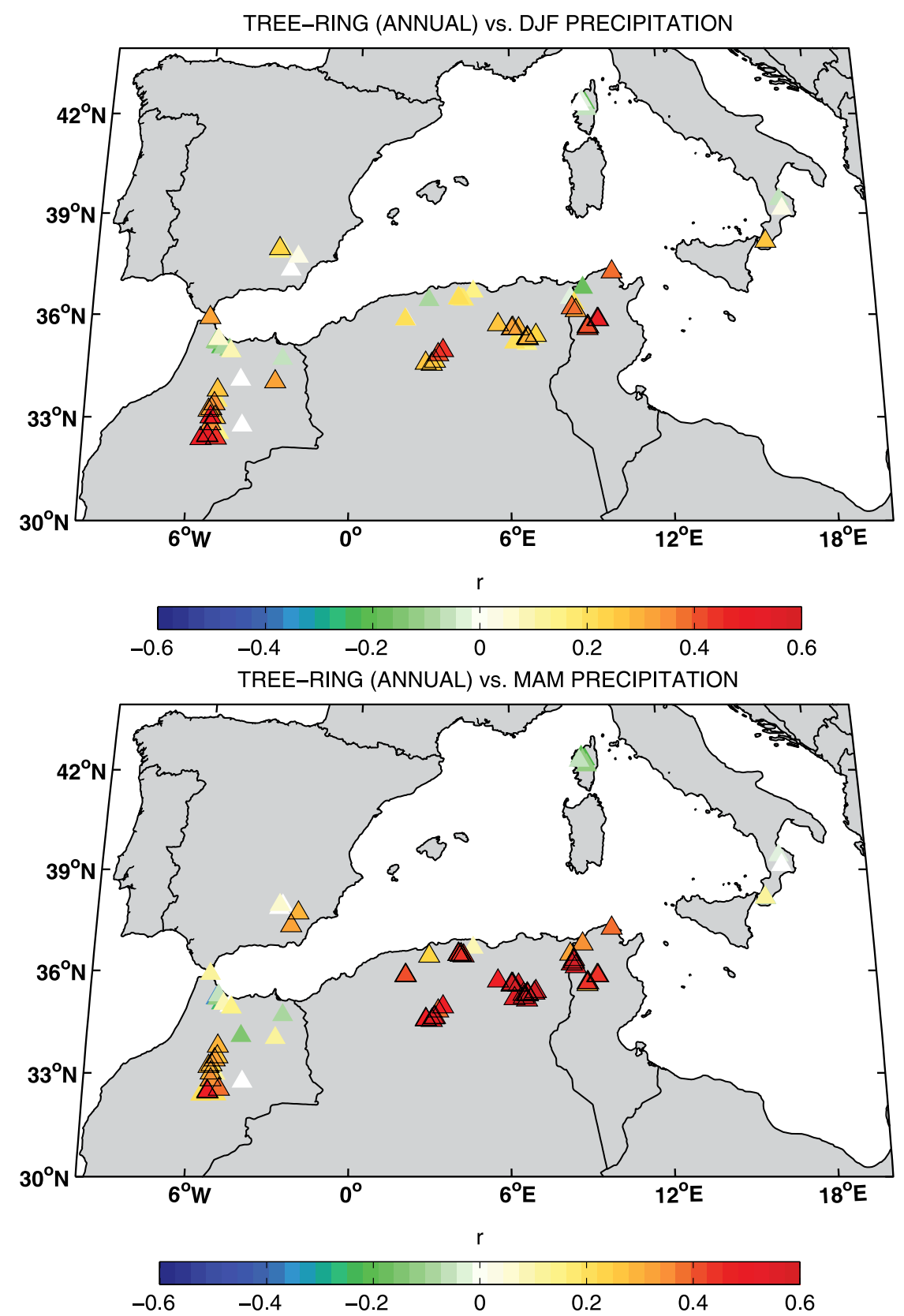

Figure 4. Correlations between individual tree-ring chronologies and their local total seasonal gridded Global Precipitation Climatology Centre (GPCC) v6 $\left(I^{\circ}\right)$ precipitation (Becker et al., 20I3; Schneider et al., 20I3). The top panel shows correlation with total winter (December-February) precipitation, while the bottom panel shows correlation with total summer (June-August) precipitation. Chronologies are correlated against the closest grid location in each dataset.

is relatively little improvement in correlation statistics compared with precipitation alone (Figure 3). These observations confirm earlier research (Cook et al., 2015; Esper et al., 2007; Touchan et al., 2008a, 2008b, 2011) that demonstrated that tree-ring chronologies in Morocco, Tunisia, and Algeria can be used for climate field reconstructions of PDSI and soil moisture; however, precipitation remains the primary control on tree growth throughout the region (Figures 3-5).

EOF analysis on our network reveals three distinct and interpretable spatial patterns associated with local and largescale climate responses (Figures 8 and 9). The first rotated mode of variability in our network is associated with the springprecipitation sensitive chronologies in Algeria and Tunisia that also have the highest correlation with MJJA PDSI. This mode of variability accounts for approximately $25 \%$ of the variance in the network. It is similar in both pattern and explained variance to the dominant unrotated mode (EOF1 with $\sim 27 \%$ of the total variance), further suggesting that the MJJA PDSI sensitivity is the primary common signal reflected across the full WM network. The second rotated mode of variability loads on those chronologies from eastern Morocco, Southeastern Spain, Corsica, and coastal Algeria that appear to have overall weaker climate signals, but which reflect some negative relationships associated with winter precipitation and positive relationships associated with winter temperature (Figure 3 ). It is possible that this mode of variability, therefore, reflects sites where growth is partially inhibited by cold and wet winter conditions (Sánchez-Salguero et al., 2015). The third rotated mode of variability loads strongly on the High Atlas chronologies of western Morocco and accounts for $6 \%$ of the total variance, but is associated with winter precipitation signals and the winter NAO (Figure 9). The NAO in western Morocco tree-ring chronologies has been detected or used in earlier works in the WM (Camarero, 2011; Glueck and Stockton, 2001; Touchan et al., 2011; Trouet et al., 2009). The spatial pattern of this mode of variability suggests that, although chronologies from Algeria 

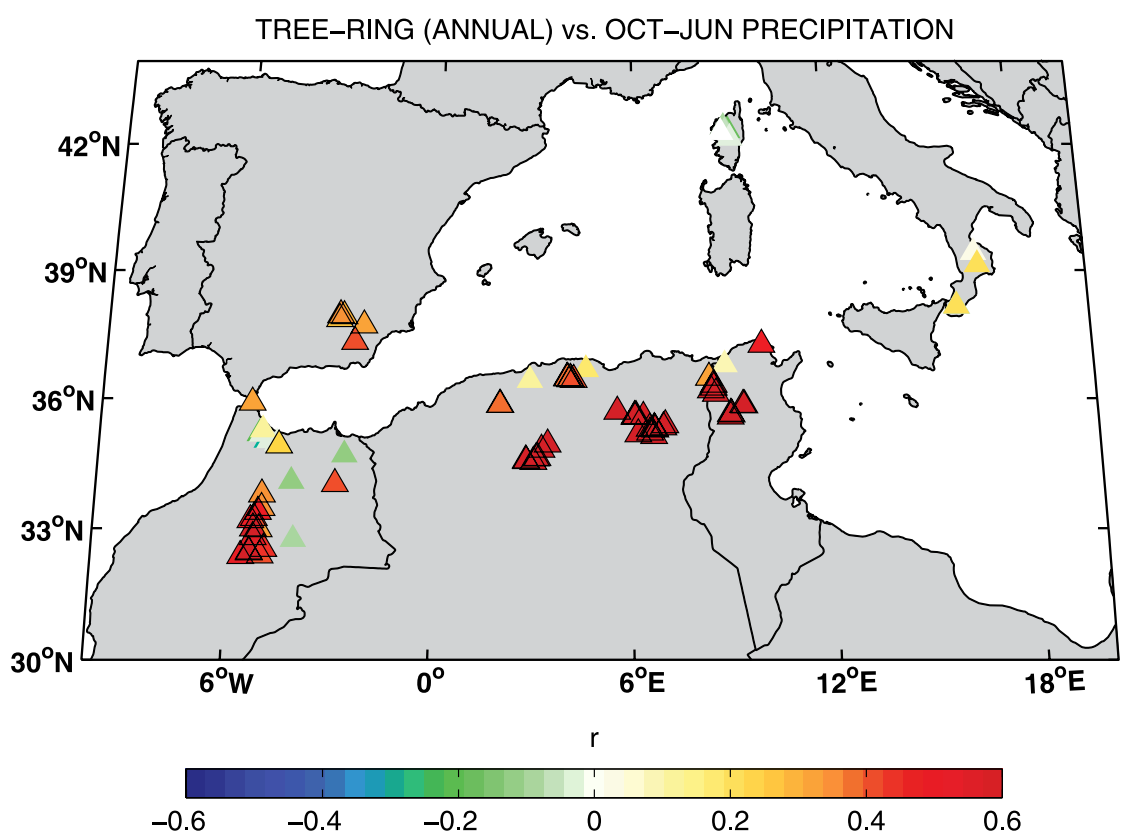

TREE-RING (ANNUAL) vs. WATER YEAR (OCT-SEP) PRECIPITATION

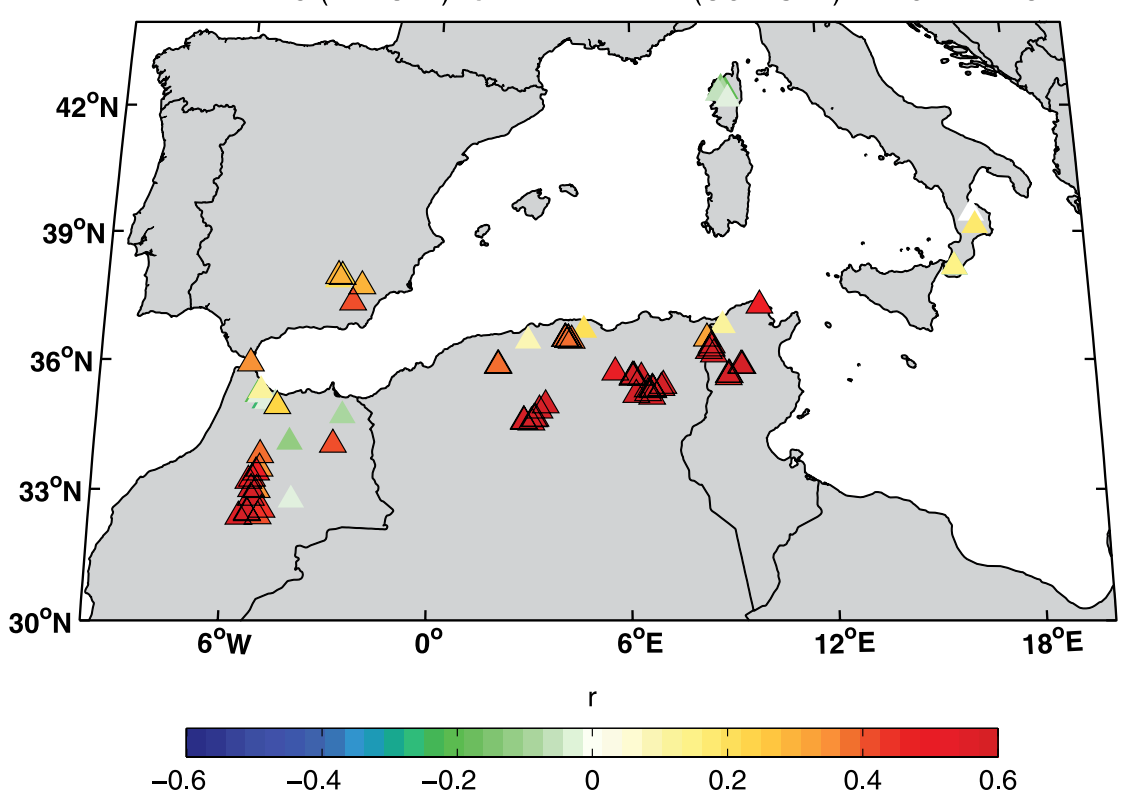

Figure 5. Correlations between individual tree-ring chronologies and their local seasonal or water year gridded Global Precipitation Climatology Centre (GPCC) v6 $\left(I^{\circ}\right)$ precipitation (Becker et al., 20I3; Schneider et al., 20I3). The top panel shows correlation with total October-June precipitation, while the bottom panel shows correlation with total October-September precipitation. Chronologies are correlated against the closest grid location.

and Tunisia do provide some additional information about winter North Atlantic variability, the western Morocco chronologies that load strongly on the third REOF have the highest correlation with the NAO index are therefore the best predictors for reconstruction of the NAO (Figure 9).

\section{Conclusion}

This study introduces a quality-controlled multi-species network of tree-ring chronologies for analysis of climate variation in the WM Basin. Chronologies from Morocco, Algeria, Tunisia, Southeastern Spain, Corsica, and Southern Italy have significant statistical relationship with the moisture and thermal regime as summarized by precipitation and temperature records. This attribute, combined with length and sample replication make the network a valuable resource for extension of climate records and documentation of climatic variability in a region predicted by models as highly sensitive to climate change associated with increasing greenhouse gases.

REOF analysis on our network reveals distinct spatial patterns associated with local and large-scale climate sensitivity. The network is dominated by three leading modes of variability. The first mode is associated with the spring-precipitation dominated chronologies in Algeria and Tunisia that also have the highest correlation with MJJA PDSI. The second mode is dominated by chronologies from eastern Morocco, Southeastern Spain, Corsica, and coastal Algeria that appear to have overall weaker climate signals. The third mode differentiates chronologies dominated by a winter precipitation signal, particularly those also associated with NAO variability in the far western portion of the network. Thus, in addition to new drought and precipitation reconstructions for the region, the network presents the opportunity for enhanced and updated tree-ring-based reconstructions of the NAO. 

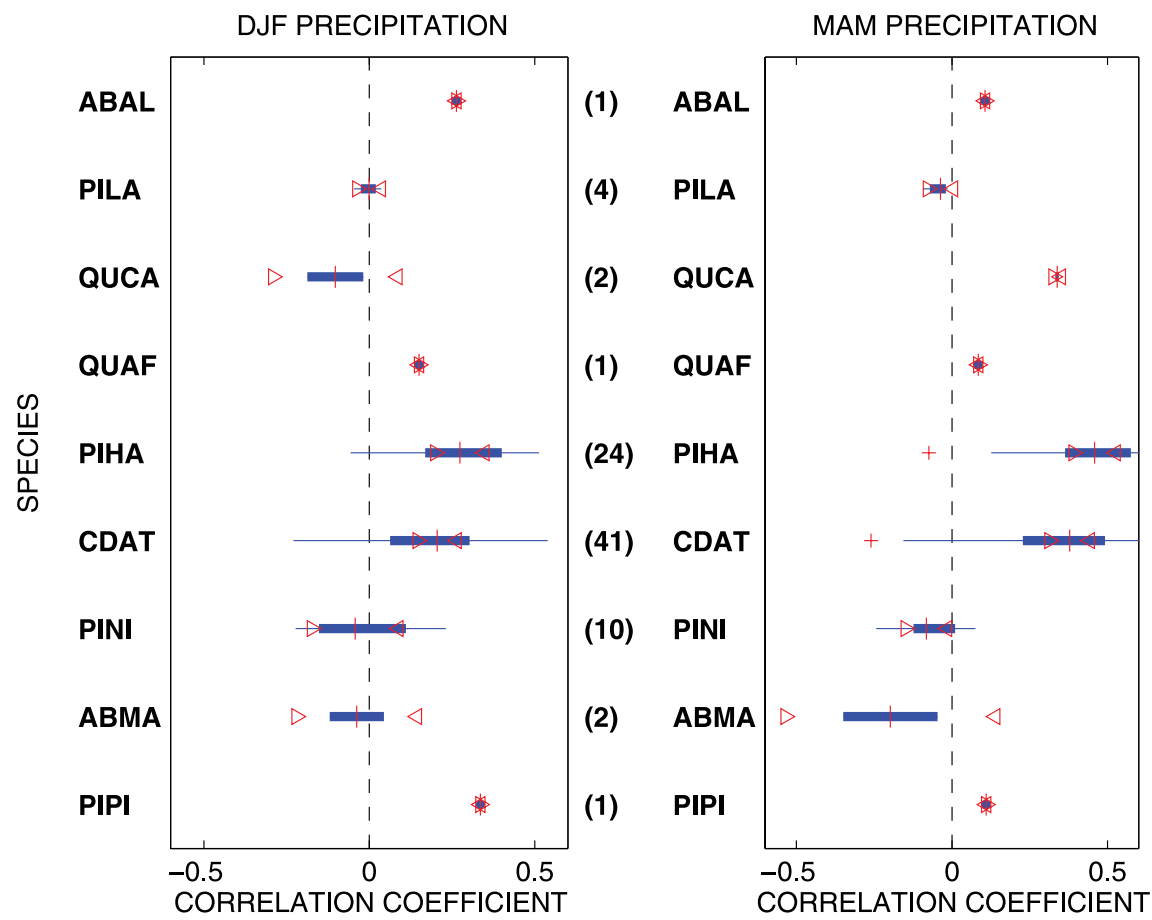

Figure 6. Correlations with seasonal precipitation as a function of species. Following Tukey (1977), filled boxes show the interquartile range for the correlations between chronologies of each species and their local winter (DJF, left panel) and summer (MAM, right panel) total precipitation, with the vertical red line indicating the median correlation for chronologies of that species. Whiskers (thin blue lines) demarcate values within 1.5 times the interquartile range and crosses are outliers. Notches (bounded by red arrowheads) that overlap indicate that the medians of the two groups do not differ significantly at the $5 \%$ level. Species codes are as in Figure I.

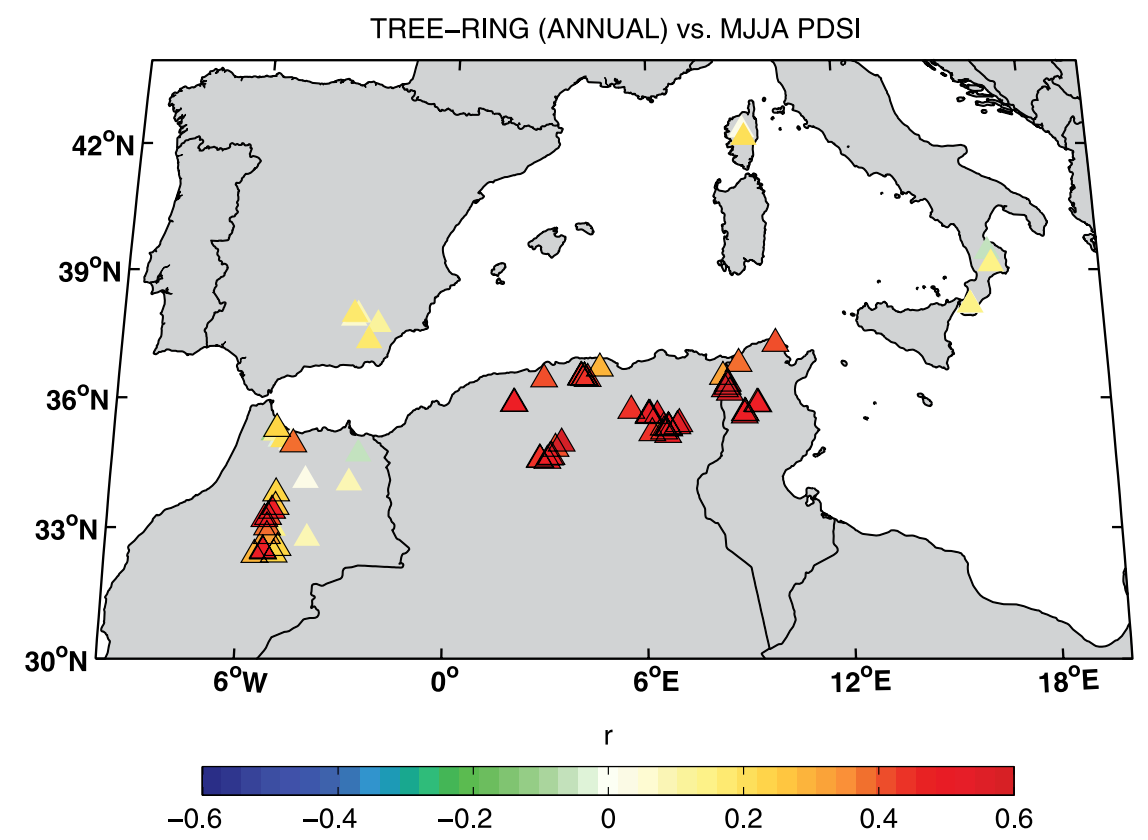

Figure 7. Correlations between individual tree-ring chronologies and May-August (MJJA) mean Penman-Monteith Palmer Drought Severity Index (PDSI; van der Schrier et al., 20I3). Chronologies are correlated against the closest grid location.

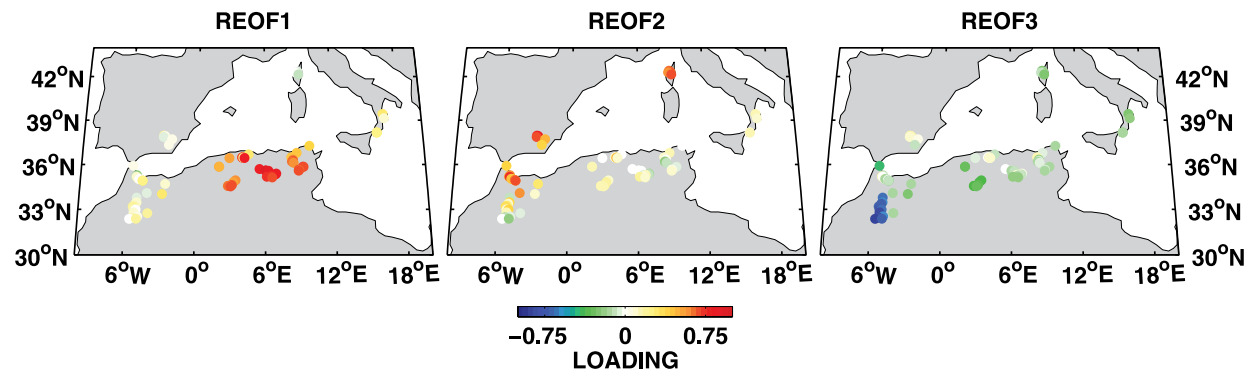

Figure 8. Rotated (varimax) empirical orthogonal function (REOF) loadings for the chronology network. 

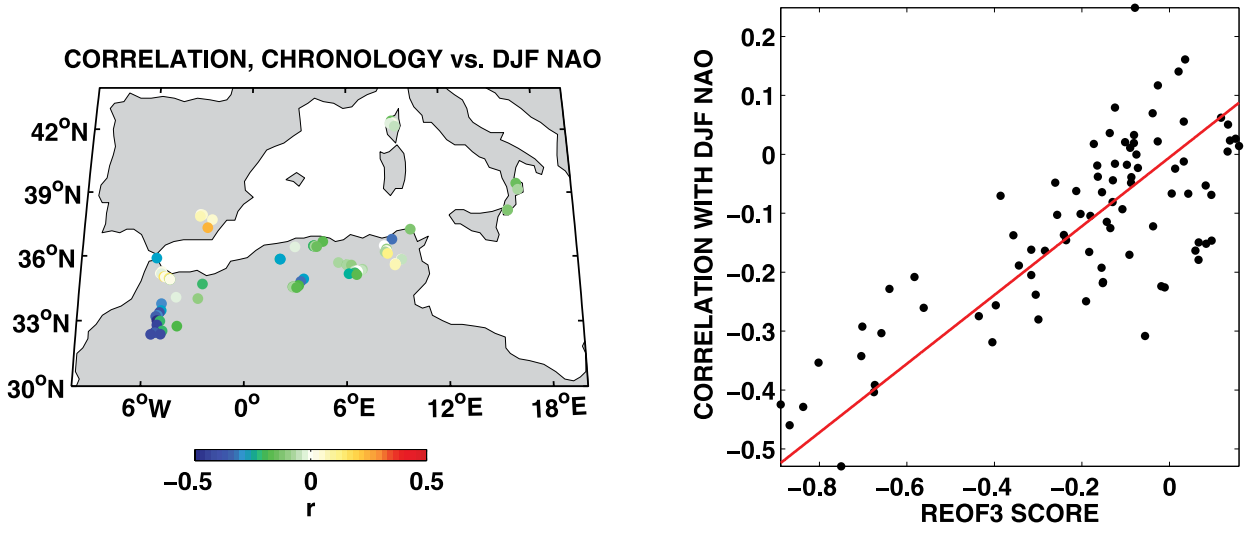

Figure 9. Correlation (left panel) between individual chronologies and the winter (DJF) North Atlantic Oscillation (NAO) Index from Jones et al. (1997). The strength of the correlation with NAO is related to the loading score of that chronology on REOF3 (see Figure 8), indicating that REOF3 reflects the large-scale signal of the NAO within our chronology network.

\section{Acknowledgements}

We thank in Morocco the Department of Forestry, the Ministry of Agriculture, and the National School of Forest Engineering; Director (Driss Misbah) and the staff of Direction of Rif of High Commissariat of Water, Forestry and Desertification Combating; Director (Abdelaziz Houseini) and the staff of Direction of Oriental of High Commissariat of Water, Forestry and Desertification Combating; Director (Mustapha Khalladi) and the staff of Direction of Moyen Atlas of High Commissariat of Water, Forestry and Desertification Combating; Chef (Mohamed Benziane) and staff of the National Center of Forestry Research; and staff of National School of forest engineers for making this study possible. We thank in Algeria the General Directorate of Forestry and its General Director Abdelmalek Titah; Abdeltatif Gasmi, the former Conservator of the Forests of Batna; Laarbi Benachoura, Messaoud Hamidi, and Salim Hadid, and the current Conservators of the Forests of Batna, Khenchela, and Djelfa, respectively, as well as Said Abderahmani, Houari Djardini, Youcef Meribai, and Ramdhane Dehal, the Directors of the National Parks of Belezma, Thniet el Had, Djurdjura, and Chréa, respectively, for their welcome and logistical support. We also are grateful to Athmane Briki, Abdelmajid Bouzghaia, Abderrahmane Rezougui, Tayeb Brima, Omar Abida, Bouhlal Saadane, Djilali Beghloul, Larbi Seddar, Moussa Haddad, and to several people from the above mentioned institutions for their help in planning and organizing the field trips. We wish to thank our colleagues from Tunisia Toumi Lamjed Directeur général de l'ISPT (Institut Sylvo-Pastoral de Tabarka), Mougou Abdelaziz Président de l'IRESA (Institution de la Recherche et de l'Enseignement Supérieur Agricole), Rejeb Néjib Directeur général de l'INRGREF (Institut national de recherche en génie rural, eaux et forêts), Fekih Salem Ahmed Ridha Directeur général des forêts, and all forest technicians of Jendouba, Siliana, Kef, and Kasserine for their great help and support in making this study possible. We thank Mohamed El Youssfi, and Rachid Azzam, and Salaheddine Saadine for their valuable field assistance. In Southern Italy, we wish to thank the following institutions and people for providing sampling authorization and logistic support: Sila National Park and Aspromonte National Park, Giuseppe Luzzi, Professor Giuliano Menguzzato, and staff of the Park Forest Service. In Southeastern Spain, we thank Consejería de Medio Ambiente y Ordenación del Territorio, Regional Government of Andalusia (Spain) for their support for our fieldworks, and Juan C. Linares and P. Tisca for providing the sampling permit and helping in the fieldwork. We thank Martin Munro for his advice and suggestions. We thank Alexis H. Arizpe, Christopher Baisan, and William E. Wright for their valuable assistance in the field. We thank Jim Burns and William E. Wright for their help in dating part of the tree-ring sites. We thank the numerous student workers who have assisted in sample preparation.

\section{Funding}

Funding was provided by the US National Science Foundation, Earth System History (ESH0317288) and Grant No. 1103314 from the National Science Foundation AGS-Paleo Perspectives on Climate Change Program.

\section{References}

Adjez A (2000) The profile of water scarcity and socio-economic outcomes in arid regions: Algeria's case. In: Abstracts of International Workshop on Climate Change: Implications for the Hydrological Cycle and for Water Management, Wengen, 27-29 September.

Aloui A (1982) Recherches dendroclimatologiques en Kroumirie [Dendroclimatological research in Kroumirie]. $\mathrm{PhD}$ Dissertation, Universite Paul Cézanne Aix-Marseille III, 109 pp. (in Tunisia).

Aloui A and Serre-Bachet F (1987) Analyse dendroclimatologique comparee de six populations de chêne zeen et d'une population de pin maritime du nord-ouest de la Tunisie [Comparative dendroclimatological analysis of six populations of Algerian oak and one population of maritime pine from northwestern Tunisia.]. Ecologia Mediterranea 13(3): 55-74.

Babst F, Poulter B, Trouet V et al. (2013) Site- and species-specific responses of forest growth to climate across the European continent. Global Ecology and Biogeography 22: 706-717.

Battipaglia G, Saurer M, Cherubini P et al. (2009) Tree rings indicate different drought resistance of a native (Abies alba Mill.) and a nonnative (Picea abies (L.) Karst.) species co-occurring at a dry site in Southern Italy. Forest Ecology and Management 257: $820-828$.

Becker A, Finger P, Meyer-Christoffer A et al. (2013) A description of the global land-surface precipitation data products of the Global Precipitation Climatology Centre with sample applications including centennial (trend) analysis from 1901-present. Earth System Science Data 5: 71-99.

Belkheiri A, Compte JP, El Khabote A et al. (1987) Bilan de cing années de secheress au Maroc. Revue Eau et Developpement 3: $10-26$.

Benzioni A and Dunstone RL (1988) Effect of air and soil temperature on water balance of jojoba growing under controlled conditions. Physiologia Plantarum 74(1): 107-112.

Berrada A (1982) A socio-economic study of the problem of drought. Revue de Géographie du Maroc 6.

Camarero JJ (2011) Direct and indirect effects of the North Atlantic oscillation on tree growth and forest decline in Northeastern Spain. In: Vicente-Serrano SM and Trigo RM (eds) Hydrological, Socioeconomic and Ecological Impacts of the North Atlantic Oscillation in the Mediterranean Region (Advances in global change research), vol. 46. Dordrecht: Springer, pp. 129-152. 
Camarero JJ, Manzanedo RD, Sánchez-Salguero R et al. (2013) Growth response to climate and drought change along an aridity gradient in the southernmost Pinus nigra relict forests. Annals of Forest Science 70: 769-780.

Camarero JJ, Olano JM and Parras A (2010) Plastic bimodal xylogenesis in conifers from continental Mediterranean climates. New Phytologist 185: 471-480.

Carrer M, Nola P, Motta R et al. (2010) Contrasting tree-ring growth to climate responses of Abies alba toward the southern limit of its distribution area. Oikos 119: 1515-1525.

Chai R and Kerrour F (2015) Contribution à l'étude de quelques aspects de la biodiversité végétale du Parc National de Thniet el Had 'partie nord-ouest du canton Pépinière'. Master's Dissertation, Université Djilali Bounaama Khemis Miliana, 58 pp.

Chbouki N (1992) Spatio-temporal characteristics of drought as inferred from tree-ring data in Morocco. PhD Dissertation, University of Arizona.

Chbouki N, Stockton CW and Myers D (1995) Spatio-temporal patterns of drought in Morocco. International Journal of Climatology 15: 187-205.

Cherubini P, Gartner BL, Tognetti R et al. (2003) Identification, measurement and interpretation of tree rings in woody species from Mediterranean climates. Biological Reviews 78: $119-148$.

Choury Z, Shestakova TA, Himrane H et al. (2016) Quarantining the Sahara desert: Growth and water-use efficiency of Aleppo pine in the Algerian Green Barrier. European Journal of Forest Research. Epub ahead of print 19 November. DOI: 10.1007/s10342-016-1014-3.

Collins M, Knutti R, Arblaster J et al. (2013) Long-term climate change: Projections, commitments and irreversibility. In: Stocker T, Qin D, Plattner GK et al. (eds) Climate Change 2013: The Physical Science Basis. Contribution of Working Group I to the Fifth Assessment Report of the Intergovernmental Panel on Climate Change. Cambridge; New York: Cambridge University Press, pp. 1029-1136.

Cook BI, Anchukaitis KJ, Touchan R et al. (2016) Spatiotemporal drought variability in the Mediterranean over the last 900 years. Journal of Geophysical Research: Atmospheres 121: 2060-2074.

Cook BI, Smerdon JE, Seager R et al. (2014) Global warming and 21 st century drying. Climate Dynamics 43(9-10): 2607-2627.

Cook ER and Holmes RL (1999) Program ARSTAN - Chronology Development with Statistical Analysis (User's manual for program ARSTAN). Tucson, AZ: Laboratory of Tree-Ring Research, University of Arizona, $18 \mathrm{pp}$.

Cook ER and Kairiukstis LA (1990) Methods of Dendrochronology: Applications in the Environmental Sciences. Doredrecht: Kluwer Academic.

Cook ER and Krusic PJ (2005) ARSTAN v. 41d: A tree-ring standardization program based on detrending and autoregressive time series modeling, with interactive graphics. Palisades, NY: Tree-Ring Laboratory, Lamont-Doherty Earth Observatory of Columbia University. Available at: http://www.ldeo. columbia.edu/tree-ring-laboratory/resources/software.

Cook ER, Briffa KR, Meko DM, et al. (1995) The 'segment length curse' in long tree-ring chronology development for paleoclimatic studies. The Holocene 5(2): 229-237.

Cook ER, Seager R, Kushnir Y et al. (2015) Old World megadroughts and pluvials during the Common Era. Science Advances 1: e1500561.

Critchfield HJ (1983) General Climatology. 4th Edition. Upper Saddle River, NJ: Prentice Hall.

De Luis M, Novak K, Raventos J, et al. (2011) Climate factors promoting intra-annual density fluctuations in Aleppo pine (Pinus halepensis) from semiarid sites. Dendrochronologia 29: $163-169$.
Esper J, Frank D, Büntgen U et al. (2007) Long-term drought severity variations in Morocco. Geophysical Research Letters 34: L17702.

Fritts H (1976) Tree Rings and Climate. London: Academic Press, $576 \mathrm{pp}$.

Gates DM (1980) Biophysical Ecology. New York: SpringerVerlag.

Giorgi F and Lionello P (2008) Climate change projections for the Mediterranean region. Global and Planetary Change 63(2-3): 90-104.

Glueck MF and Stockton CW (2001) Reconstruction of the North Atlantic oscillation, 1429-1983. International Journal of Climatology 21: 1453-1465.

Halimi A (1980) L'Atlas Blidéen: Climat et étages végétaux. Algiers: Office des publications universitaires (OPU), $523 \mathrm{pp}$.

Harris I, Jones PD, Osborn TJ et al. (2014) Updated highresolution grids of monthly climatic observations - the CRU TS3.10 Dataset. International Journal of Climatology 34: 623-642.

Hazell P (2000) Public policy and drought management in agropastoral systems. In: McCarthy N, Swallow B and Kirk M (eds) Property Rights, Risk, and Livestock Development in Africa. Washington, DC: International Food Policy Research Institute; Nairobi: IFPRI, International Livestock Research Institute ILRI, pp. 86-102.

Hetzer T, Brauning A and Leuschner HH (2014) High-resolution climatic analysis of wood anatomical features in Corsican pine from Corsica (France) using latewood tracheid profiles. Trees-Structure and Function 28: 1279-1288.

Hoerling M, Eischeid J, Perlwitz J et al. (2012) On the increased frequency of Mediterranean drought. Journal of Climate 25: 2146-2161.

Holobâcă IH, Pop O, Marinică I et al. (2015) Reconstruction dendroclimatique des températures et précipitations dans les carpates méridionales. In: XXVIIIe Colloque de l'Association Internationale de Climatologie, Liège, 1-4 July, pp. 158-163.

Isendahl N and Schmidt G (2006) Drought in the Mediterranean: WWF Policy Proposals. Madrid: WWF-Worldwide Fund for Nature, 41 pp. Available at: http://assets.panda.org/downloads/wwf_drought_med_report_2006.pdf.

Jolliffe IT (2002) Principal Component Analysis. 2nd Edition. New York: Springer-Verlag.

Jones PD, Jónsson T and Wheeler D (1997) Extension to the North Atlantic Oscillation using early instrumental pressure observations from Gibraltar and South-West Iceland. International Journal of Climatology 17: 1433-1450.

Kaiser HF (1958) The varimax criterion for analytic rotation in factor analysis. Psychometrika 23(3): 187-200.

Kassoul A and Maougal ML (2006) The Algerian Destiny of Albert Camus. Palo Alto, CA: Academica Press.

Kherchouche D, Kalla M, Gutiérrez E et al. (2012) Impact of Droughts on Cedrus atlantica Forests Dieback in the Aurès (Algeria). Journal of Life Sciences 6: 1262-1269.

Kozlowski TT (1987) Soil moisture and absorption of water by tree roots. Journal of Arboriculture 13(2): 39-46.

Kozlowski TT and Pallardy SG (1997) Growth control in woody plants. In: Mooney HA (ed.) Physiological Ecology. San Diego, CA: Academic Press, 641 pp.

Linares JC, Taïqui L and Camarero JJ (2011) Increasing drought sensitivity and decline of Atlas cedar (Cedrus atlantica) in the Moroccan Middle Atlas forests. Forests 2: 777-796.

Masih I, Maskey S, Mussá FEF et al. (2014) A review of droughts on the African continent: A geospatial and longterm perspective. Hydrology and Earth System Sciences 18: 3635-3649.

Meddi M and Toumi S (2013) Study of the interannual rainfall variability in northern Algeria. LJEE 23: 40-59. 
Meddour R (2010) Bioclimatologie, phytogéographie et phytosociologie en Algérie. Exemple des groupements forestiers et préforestiers de la Kabylie Djurdjuréenne, Thèse de Doctorat d'État, Université Mouloud Mammeri de Tizi Ouzou, 397 pp.

Meko DM, Touchan R and Anchukaitis KJ (2011) Seascorr: A MATLAB program for identifying the seasonal climate signal in an annual tree-ring time series. Computers \& Geosciences 37: $1234-1241$.

Messaoudene M and Tessier L (1997) Relations cerne-climat dans des peuplements de Quercus afares Willd et Quercus canariensis Pomel en Algerie [Tree-ring-climate relationships for populations of Quercus afares Willd. and Quercus canariensis Pomel in Algeria.]. Annales des Sciences forestieres 54: 347-358.

Meyers AR (1981) Famine relief and imperial policy in early modern Morocco: The political functions of public health. American Journal of Public Health 71(11): 1266-1273.

Monahan AH, Fyfe JC, Ambaum MHP et al. (2009) Empirical orthogonal functions: The medium is the message. Journal of Climate 22(24): 6501-6514.

Navarra A and Simoncini V (2010) A Guide to Empirical Orthogonal Functions for Climate Data Analysis. New York: Springer.

Nicholson SE and Wigley TML (1984) Drought in Morocco. I. The General Climatology of Drought (Report to the conseil superieur de l'eau, Morocco).

Parent C, Capelli N, Berger A et al. (2008) An overview of plant responses to soil waterlogging. Plant Stress 2(1): 20-27.

Pavel EW and Fereres E (1998) Low soil temperatures induce water deficits in olive (Olea europaea) trees. Physiologia Plantarum 104(4): 525-532.

Percival DB and Constantine WL (2006) Exact simulation of Gaussian time series from nonparametric spectral estimates with application to bootstrapping. Statistics and Computing 16(1): 25-35.

Richman MB (1986) Rotation of principal components. International Journal of Climatology 6: 293-335.

Safar W, Serre-Bachet F and Tessier L (1992) Les plus vieux pins d'Alep vivants connus. Dendrochronologia 10: 41-52.

Sánchez-Salguero R, Camarero JJ, Hevia A et al. (2015) What drives growth of Scots pine in continental Mediterranean climates: Drought, low temperatures or both? Agricultural and Forest Meteorology 206: 151-162.

Sánchez-Salguero R, Navarro-Cerillo RM, Camarero JJ et al. (2012) Selective drought-induced decline of pine species in southeastern Spain. Climatic Change 113: 767-785.

Scheff J and Frierson DM (2015) Terrestrial aridity and its response to greenhouse warming across CMIP5 climate models. Journal of Climate 28(14): 5583-5600.

Schilling J, Freier KP, Hertig E et al. (2012) Climate change, vulnerability and adaptation in North Africa with focus on Morocco. Agriculture Ecosystems \& Environment 156: 12-26.

Schneider U, Becker A, Finger P et al. (2011) GPCC Full Data Reanalysis Version 6.0 at 1.0: Monthly Land-Surface Precipitation from Rain-Gauges built on GTS-based and Historic Data. doi:10.5676/DWD GPCC/FD M V7 100.

Schneider U, Becker A, Finger P et al. (2013) GPCC's new land surface precipitation climatology based on quality-controlled in situ data and its role in quantifying the global water cycle. Theoretical and Applied Climatology 115: 15-40.

Seager R, Liu H, Henderson N et al. (2014) Causes of increasing aridification of the Mediterranean region in response to rising greenhouse gases. Journal of Climate 27(12): 4655-4676.

Serre-Bachet F (1969) Variations de l'epaisseur des anneux chez le Thuya de Barbarie (Tetraclinis articulata (Vahl) Mast.) et climat en Tunisie. Annales de la Faculte des Sciences de Marseille 42: 193-204.

Slimani S, Derridj A and Gutierrez E (2014) Ecological response of Cedrus atlantica to climate variability in the Massif of Guetiane (Algeria). Forest Systems 23(3): 448-460.

Stokes A (2000) The Supporting Roots of Trees and Woody Plants: Form, Function and Physiology (Developments in plant and soil sciences), vol. 87. Dordrecht: Springer.
Stokes MA and Smiley M (1968) An Introduction to Tree-Ring Dating. Chicago, IL: University of Chicago Press.

Suvanto S (2014) Phloem transport and drought. Journal of Experimental Botany 65: 1151-1759.

Swearingen WD (1988) Moroccan Mirages: Agrarian Dreams and Deceptions, 1912-1986. London: I.B. Tauris.

Swearingen WD (1992) Drought hazard in Morocco. Geographical Review 82(4): 401-412.

Tessier L, Nola P and Serre-Bachet F (1994) Deciduous Quercus in the Mediterranean region: Tree-ring/climate relationships. New Phytologist 126: 355-367.

Till C and Guiot J (1990) Reconstruction of precipitation in Morocco since 1100 A.D. based on Cedrus atlantica tree-ring widths. Quaternary Research 33: 337-351.

Todaro T, Andreu L, D'alessandro CM et al. (2007) Response of Pinus leucodermis to climate and anthropogenic activity in the National Park of Pollino (Basilicata, Southern Italy). Biological Conservation 137: 507-519.

Touazi M and Laborde JP (2004) Modélisation pluie-débit à l'échelle annuelle en Algérie du Nord. Revue des sciences de l'eau 17(4): 503-516.

Touchan R and Hughes MK (1999) Dendrochronology in Jordan. Journal of Arid Environments 42: 291-303.

Touchan R, Meko DM and Aloui A (2008b) Precipitation reconstruction for northwestern Tunisia from tree Rings. Journal of Arid Environments 72: 1887-1896.

Touchan R, Anchukaitis KJ, Meko DM et al. (2008a) Long term context for recent drought in northwestern Africa. Geophysical Research Letters 35: L13705.

Touchan R, Anchukaitis KJ, Meko DM et al. (2011) Spatiotemporal drought variability in northwestern Africa over the last nine centuries. Climate Dynamics 37: 237-252.

Touchan R, Anchukaitis KJ, Shishov V et al. (2014) Spatial patterns of Eastern Mediterranean climate influence on tree growth. The Holocene 24(4): 381-392.

Touchan R, Kherchouche D, Oudjehih B et al. (2016) Dendroclimatology and wheat production in Algeria. Journal of Arid Environments 124: 102-110.

Touchan R, Shishov VV, Meko DM et al. (2012) Process based model sheds light on climate sensitivity of Mediterranean tree-ring width. Biogeosciences 9: 965-972.

Touchan R, Xoplaki E, Funkhouser G, et al. (2005) Dendroclimatology and large-scale circulation influences in the eastern Mediterranean and Near East region. Climate Dynamics 25: 75-98.

Trouet V, Esper J, Graham NE et al. (2009) Persistent positive North Atlantic oscillation mode dominated the Medieval Climate Anomaly. Science 324: 78-80.

Tukey JW (1977) Exploratory Data Analysis. Reading, MA: Addison-Wesley.

Van der Schrier G, Barichivich J, Briffa KR et al. (2013) A scPDSI-based global data set of dry and wet spells for 19012009. Journal of Geophysical Research: Atmospheres 118: 4025-4048.

Velmex Inc. (2016) Velmex Measurement System. Bloomfield, NY: Velmex Inc.

Vernieri P, Pardossi A and Tognoni F (1991) Influence of chilling and drought on water relations and abscisic acid accumulation in bean. Australian Journal of Plant Physiology 18: 25-35.

Vicente-Serrano SM, Gouveia C, Camarero JJ et al. (2013) Response of vegetation to drought time-scales across global land biomes. Proceedings of the National Academy of Sciences of the United States of America 110: 52-57.

Wigley TML, Briffa KR and Jones PD (1984) On the average value of correlated time series, with applications in dendroclimatology and hydrometeorology. Journal of Climate and Applied Meteorology 23: 201-213.

Zappa G, Hawcroft MK, Shaffrey L et al. (2015) Extratropical cyclones and the projected decline of winter Mediterranean precipitation in the CMIP5 models. Climate Dynamics $45(7-$ 8): $1727-1738$. 